All102 b55453

NBS PUBLICATIONS

NATL INST OF STANDARDS \& TECH R.I.C.

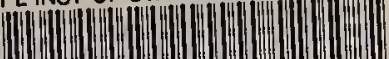

A11102655453

Scribner, Charles/National earthquake en

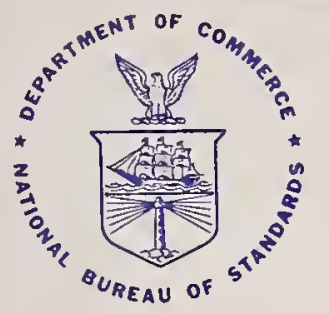

NBS SPECIAL PUBLICATION 729

U.S. DEPARTMENT OF COMMERCE/National Bureau of Standards

\title{
National Earthquake Engineering Experimental Facility Study
}

Phase One - Large Scale Testing Needs 
he National Bureau of Standards' was established by an act of Congress on March 3, 1901. The Bureau's overall goal is to strengthen and advance the nation's science and technology and facilitate their effective application for public benefit. To this end, the Bureau conducts research and provides: (1) a basis for the nation's physical measurement system, (2) scientific and technological services for industry and government, (3) a technical basis for equity in trade, and (4) technical services to promote public safety. The Bureau's technical work is performed by the National Measurement Laboratory, the National Engineering Laboratory, the Institute for Computer Sciences and Technology, and the Institute for Materials Science and Engineering.

\section{The National Measurement Laboratory}

Provides the national system of physical and chemical measurement; coordinates the system with measurement systems of other nations and furnishes essential services leading to accurate and uniform physical and chemical measurement throughout the Nation's scientific community, industry, and commerce; provides advisory and research services to other Government agencies; conducts physical and chemical research; develops, produces, and distributes Standard Reference Materials; and provides calibration services. The Laboratory consists of the following centers:
- Basic Standards ${ }^{2}$

- Radiation Research

- Chemical Physics

- Analytical Chemistry

\section{The National Engineering Laboratory}

Provides technology and technical services to the public and private sectors to address national needs and to solve national problems; conducts research in engineering and applied science in support of these efforts; builds and maintains competence in the necessary disciplines required to carry out this research and technical service; develops engineering data and measurement capabilities; provides engineering measurement traceability services; develops test methods and proposes engineering standards and code changes; develops and proposes new engineering practices; and develops and improves mechanisms to transfer results of its research to the ultimate user. The Laboratory consists of the following centers:
- Applied Mathematics

- Electronics and Electrical Engineering $^{2}$

- Manufacturing Engineering

- Building Technology

- Fire Research

- Chemical Engineering ${ }^{2}$

\section{The Institute for Computer Sciences and Technology}

Conducts research and provides scientific and technical services to aid Federal agencies in the selection, acquisition, application, and use of computer technology to improve effectiveness and economy in Government operations in accordance with Public Law 89-306 (40 U.S.C. 759), relevant Executive Orders, and other directives; carries out this mission by managing the Federal Information Processing Standards Program, developing Federal ADP standards guidelines, and managing Federal participation in ADP voluntary standardization activities; provides scientific and technological advisory services and assistance to Federal agencies; and provides the technical foundation for computer-related policies of the Federal Government. The Institute consists of the following centers:
- Programming Science and Technology

- Computer Systems Engineering

\section{The Institute for Materials Science and Engineering}

Conducts research and provides measurements, data, standards, reference materials, quantitative understanding and other technical information fundamental to the processing, structure, properties and performance of materials; addresses the scientific basis for new advanced materials technologies; plans research around cross-country scientific themes such as nondestructive evaluation and phase diagram development; oversees Bureau-wide technical programs in nuclear reactor radiation research and nondestructive evaluation; and broadly disseminates generic technical information resulting from its programs. The Institute consists of the following Divisions:
- Ceramics

- Fracture and Deformation 3

- Polymers

- Metallurgy

- Reactor Radiation

\footnotetext{
Headquarters and Laboratories at Gaithersburg, MD, unless otherwise noted; mailing address Gaithersburg, MD 20899.

${ }^{2}$ Some divisions within the center are located at Boulder, CO 80303.

${ }^{3}$ Located at Boulder, CO, with some elements at Gaithersburg, MD.
} 


\section{National Earthquake Engineering Experimental Facility Study}

Phase One - Large Scale Testing Needs

Charles F. Scribner and Charles G. Culver

Center for Building Technology

National Bureau of Standards

U.S. Department of Commerce

Gaithersburg, MD 20899

Sponsored by:

Federal Emergency Management Agency

National Science Foundation

National Bureau of Standards

April 1987 
Library of Congress Catalog Card Number: 87-619811

National Bureau of Standards Special Publication 729

Natl. Bur. Stand. (U.S.), Spec. Publ. 729, 70 pages (Apr. 1987) CODEN:XNBSAV 


\begin{abstract}
This report summarizes information obtained during the first year of a four-year feasibility study for a national earthquake engineering experimental facility. A five-year research program is presented for a national facility in which full-scale or large-scale structures or structural components would be subjected to static or dynamic lateral loads. The facility would have applicability to tests in the following areas: low-rise buildings, medium-rise buildings, high-rise buildings, industrial processing facilities, and power facilities. Representatives from a broad spectrum of professional, industrial, and trade organizations and Federal agencies participated in developing the research program. A comparison of existing testing facilities in the U.S. and other countries engaged in seismic testing and a discussion of international cooperation in large-scale testing are included.
\end{abstract}

Keywords: Buildings, Earthquakes, Laboratories, Research, structural engineering, Tests 


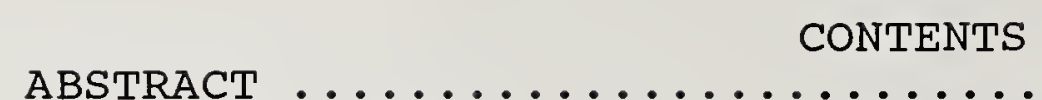

EXECUTIVE SUMMARY $\ldots \ldots \ldots \ldots \ldots \ldots \ldots \ldots \ldots \ldots \ldots \ldots \ldots \ldots \ldots \ldots$

INTRODUCTION $\ldots \ldots \ldots \ldots \ldots \ldots \ldots \ldots \ldots \ldots \ldots \ldots \ldots \ldots$

Background $\ldots \ldots \ldots \ldots \ldots \ldots \ldots \ldots \ldots \ldots \ldots \ldots \ldots \ldots$

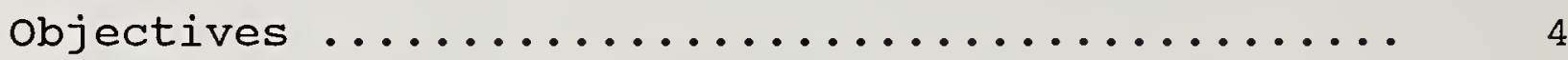

Summary of Phase one Activities ............... 5

EXPERIMENTAL NEEDS FOR LARGE-SCALE SEISMIC TESTS ..... 6

EXISTING FACILITIES FOR LARGE-SCALE TESTING ......... 12

CONCLUSIONS $\ldots \ldots \ldots \ldots \ldots \ldots \ldots \ldots \ldots \ldots \ldots \ldots \ldots \ldots \ldots \ldots \ldots$

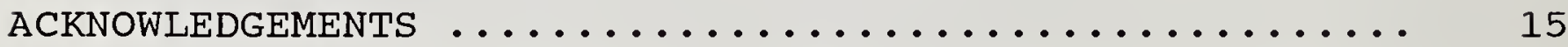

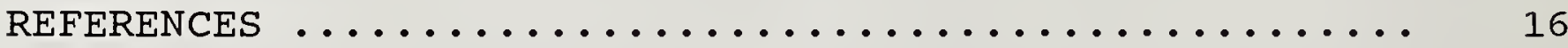

APPENDICES

Appendix A - Summary of Previous Workshops ....... 18

Appendix B - Survey of Facilities Worldwide ...... 23

Appendix C - International Activities and

Cooperative Research ...................... 37

Appendix D - Workshop ..................... 46

Appendix E - Recommendations for Large-Scale

Testing ..................... 51

Appendix F - National Academy of Science

Advisory Panel ...............

64 


\section{EXECUTIVE SUMMARY}

This report presents results obtained during the first year (Phase I) of a four-year study to obtain the data needed to compare the cost-effectiveness of alternative methods of obtaining needed full- or large-scale experimental data on seismic response of structures. During Phase I of the study the objective was to determine existing experimental needs for largescale testing. This study was initiated in 1985 by the National Bureau of standards following a recommendation in 1984 by the National Research Council that the Federal government undertake planning aimed at establishing the feasibility of a major national earthquake engineering experimental/test facility.

During Phase I of the study, needs for full-scale seismic testing were determined by a broad spectrum of practicing professionals, researchers, industry representatives, building officials, and Federal agency representatives. consulting engineers developed initial recommendations $(5,6,7,8,9,10)$. These initial recommendations were refined at a workshop held by the National Bureau of Standards in Gaithersburg, Maryland in November 1986. Five areas in which testing needs were identified included: low-rise, medium-rise, and high-rise buildings, industrial processing facilities, and power facilities. Specific tests were recommended which made up a three- to five-year testing program.

The testing needs highlight several general problem areas requiring full-scale testing for each category. For low-rise buildings (5), for example, the interaction between roofs and walls, connection behavior, and the behavior of nonstructural elements are important. In medium-rise buildings (6), tests of buildings of the type built in low seismic risk areas, ground motion isolation devices, and the contribution of nonstructural elements to lateral stiffness and strength need to be studied. The key issues for high-rise buildings (7) are the redistribution of forces in the structure following localized yielding, the significance of second-order P-delta effects, and the force distribution in dual systems. Tests of tank structures, pressure vessels and piping, and the effectiveness of retrofit measures are important for industrial process facilities (8). Qualification tests and tests of unique components for which small-scale test data is difficult to extrapolate to full scale are needed for power facilities (9).

In addition, the workshop participants concluded that:

* There are significant needs for information about structural behavior during earthquakes that can be best satisfied by full- or large-scale testing. 
* Detailed estimates are needed to determine the configuration and cost of a large facility capable of performing the required tests.

* Comparisons of the relative costs and benefits of alternative methods for conducting the tests are needed.

One critical issue is the lack of large-scale testing facilities in the United States. A comparison of testing facilities in the U.S. and other countries engaged in seismic testing indicates that the facilities of the U.S. generally are smaller and less adequate than those of Japan, which has the most complete facilities of any nation in the world for seismic experimentation. Although there have been several cooperative experimental research programs in which the U.S. and Japan have shared results, the consensus in the U.S. is that the facilities of the Japanese should not be viewed as a permanent substitute for adequate facilities in this country.

Direct and indirect benefits will be derived from construction and use of a national facility to conduct largescale seismic testing. Direct benefits applicable to U.S. construction include methods for identifying existing buildings that need strengthening to improve their earthquake resistance, identification of economical methods for strengthening buildings, an ability to improve design procedures for future construction, and an ability to perform proof-testing of critical components of power and industrial facilities. It was estimated that data from full-scale tests of high-rise buildings could save as much as 2$3 \%$ of the cost of the structural system. This information will also have direct benefits in terms of making the U.S. competitive in international markets. It will insure that the U.S. is among the world's leaders in marketing engineering services and seismic-resistant structures and equipment. 


\section{INTRODUCTION}

\section{BACKGROUND}

In 1984 the National Research Council (NRC) published the results of its 6-month study on "Earthquake Engineering Facilities and Instrumentation" (1) requested by the office of Science and Technology Policy (OSTP). The report contained a number of conclusions, including the following:

* "There is near unanimity within the earthquake engineering community that a need exists for data on the behavior of earthquake-excited full-scale multistory structures from the initiation of structural damage to collapse.

* "The irreducible need for full-scale data on the behavior of earthquake-impacted multistory structures requires that the nation have experimental facilities able to test such structures across a range from damage initiation to collapse. At present, no adequate facilities for testing full-scale structures exist in the United States. A variety of alternative experimental/test facilities have been proposed. These include shaking tables, reaction walls, instrumented buildings in earthquake-prone areas, explosive tests, and tests on prototype structures.

* The federal government should immediately initiate a conceptual engineering design study of a national earthquake engineering experimental/test facility capable of both dynamically and statically testing full- or nearly full-scale multistory buildings to destruction in a simulated earthquake environment. The engineering design study should focus on a large shaking table of a size substantially larger than is now available in Japan. The engineering design study for the large shaking table should be used as a source of data for making a careful comparison with alternative full- or nearly full-scale methods of obtaining the needed experimental data."

One of the major recommendations of the report with regard to the latter conclusion was that "The federal government should undertake, on an accelerated basis, planning aimed at developing a major national earthquake engineering experimental/test facility. The goals of that facility should be to provide the data and understanding necessary for rapid improvement in the design and construction of seismic-resistant structures." 
The Science Advisor to the President urged the Federal Emergency Management Agency (FEMA) to initiate the planning study called for in the NRC report and to obtain information which could be used as the basis for a decision on the need for and the requirements of a national earthquake engineering experimental facility. To respond to this request, this study was included in the five-year plan for the earthquake hazard reduction program for fiscal years 1985-89 (2) as objective 5 of the program on Seismic Design and Engineering Research.

At the request of FEMA, the Policy Coordination Group (PCG) of the National Earthquake Hazards Reduction Program (NEHRP) considered the scope of a planning study and the alternatives for funding the study. On the basis of these deliberations, the PCG recommended that the National Bureau of Standards (NBS) proceed with the planning study.

The National Bureau of Standards and FEMA negotiated an interagency agreement in 1985 (3) in which FEMA agreed to provide principal funding and overall guidance and direction to the management of the study. NBS assumed responsibility for management and technical content of the study and agreed to coordinate with FEMA, NSF, and USGS throughout the study. NBS initiated the study in 1985 and developed a plan for a four-year study (4) covering all aspects of planning for a national experimental facility, including research needs, facility characteristics, siting, and management.

The information in this report is part of the four-year study; it contains recommendations for testing developed during the first year (Phase I) of the study. Objectives of the first phase of the study were to determine critical data needs on fullscale structural behavior and development of the requirements for a facility to conduct the program of testing required to satisfy those needs. Subsequent phases of the study are intended to produce a preliminary design and cost estimate for a large shaking table and reaction wall (Phase II), information on costeffectiveness of alternative types of facilities which could satisfy the testing needs (Phase III), and recommendations for the siting, operational, and management requirements for a proposed facility (Phase IV).

\section{$\underline{\text { OBJECTIVES }}$}

The objectives of the first year of the study were to determine the needs of users for a national earthquake engineering experimental facility, to develop an experimental laboratorybased program of three to five years duration for the facility, and to identify the benefits to be gained by the nation, the engineering profession and the building community from such a facility. 
It should be noted that not all tests required to study behavior of all types of buildings under seismic loading can be conducted in a laboratory environment. For obvious reasons, tests of full-scale, high-rise buildings or of other very large structures cannot be conducted in a laboratory. A national laboratory facility would not be intended to eliminate in-situ testing of existing structures by eccentric or reciprocating mass vibrators, pull-back and release methods, high-explosive excitation methods, or instrumentation of buildings in areas of high earthquake risk. One objective of phase III of the study will be to evaluate the relative advantages of alternative test methods and different types of facilities in providing the most effective and economical contributions to seismic-resistant design and construction.

\section{SUMMARY OF PHASE ONE ACTIVITIES}

The first task involved collecting background data to provide a perspective for research needs and to establish the state of experimental capabilities in the U.S. and worldwide. Previous workshops held in the United States to consider the needs for and benefits of large testing facilities were reviewed. A summary of these workshops is included in Appendix A. A summary of the state of existing experimental/test facilities in the U.S. and worldwide is given in Appendix B. Current activities of other nations engaged in testing of structures under simulated seismic loading are summarized in Appendix C.

The second task involved determining specific experimental research needs requiring facilities larger than those currently available in the U.S. These were determined through a workshop involving participation by representatives of professional, industrial, and trade organizations and Federal agency representatives. Organization of the workshop is discussed in Appendix D. The workshop recommendations are presented in Appendix E.

At the request of NBS and FEMA, the National Research Council established a panel to evaluate the procedures being used by NBS throughout this phase of the study. This panel was responsible for providing review and advice to the study. They also commented on all work plans and drafts of publications produced by NBS. In addition, the panel members attended the user needs workshop held in Gaithersburg in November 1986, commented on results of the study, and provided an independent statement of user needs on the basis of their experience and judgement. 


\section{EXPERIMENTAL NEEDS FOR LARGE-SCALE SEISMIC TESTS}

The broad spectrum of needs for a national earthquake engineering experimental facility were aggregated into six areas of interest: low-rise buildings, medium-rise buildings, highrise buildings, industrial processing facilities, power facilities, and lifelines.

No specific recommendations, for the type of testing considered in this study, were developed for lifelines at the workshop as noted in Appendix E. However, the working group which considered lifelines during the workshop did determine a need for in situ and laboratory testing to satisfy certain testing requirements for bridges and other lifeline facilities. Among these testing needs were:

* Tests of linear structural elements to examine the effects of skewed spans, joints, and impacting between elements

* Tests of various retrofit techniques on long linear elements, determination of energy absorption characteristics, and experimental verification of simplified analytical procedures for retrofit components

* Tests to determine effects of yield sequence on long linear systems

* Tests to study effects of spatially varying ground motions on response of long, multi-supported structures

* Tests to determine the effects of soil-structure interaction on response of lifeline facilities to severe ground shaking

The workshop working group considering lifelines also discussed the possibility of using several modular shaking tables to either simulate independent support motions or to act in a "ganged" format as a single large table. This concept of linking several independent tables to form one large table is an idea which could be considered as an alternative to a single large table in future phases of this study.

A summary of the testing needs in the five categories is given in Table 1. Specific recommendations for testing in the five areas are given in Appendix $\mathrm{E}$. These testing needs reflect priorities determined by researchers, designers, manufacturers, builders, owners, regulators, and code writers represented at the workshop. 
The testing needs listed in Table 1 indicate two key points in regard to the anticipated use of the facility. First, the facility is expected to serve the needs of the building community to provide data on performance of existing structures and to improve future construction. Second, it is anticipated that a significant amount of testing will be dedicated to evaluating non-structural items such as the equipment used in industrial or power facilities.

Several benefits would result from use of a large-scale testing facility. Experimental data are needed on the seismic resistance of existing buildings because changes in construction practices over time and degradation of material properties from as-built values make it difficult to calculate this resistance. This information would help to identify those types of structures which most need strengthening and would identify the most economical means of strengthening. Second, tests would provide data to identify improved design details for new structures. It was estimated this information could save as much as $2-3 \%$ of the cost of the structural system for high-rise buildings. Similar cost savings would probably result in other types of structures. These cost savings would offset the modest increase in building costs associated with the adoption of seismic design requirements in areas of the country which currently do not have such requirements.

The testing needs summarized in Appendix E highlight several general problem areas requiring full-scale testing for each category. For low-rise buildings, for example, the interaction between roofs and walls, connection behavior, and the behavior of nonstructural elements are important. In medium-rise buildings, tests of buildings of the type built in low seismic risk areas, ground motion isolation devices, and the contribution of nonstructural elements to lateral stiffness and strength need to be studied. The key issues for high-rise buildings are the redistribution of forces in the structure following localized yielding, the significance of second-order P-delta effects, and the force distribution in dual systems. Tests of tank structures, pressure vessels and piping, and the effectiveness of retrofit measures are important for industrial process facilities. Qualification tests and tests of unique components for which small-scale test data is difficult to extrapolate to full scale are needed for power facilities.

For the purposes of this study, only those tests which could best be performed in a central facility using reaction walls and shaking tables were considered. As noted previously, it was the objective of this phase of the study to identify the specific needs for these types of facilities. A determination of the desirability of the use of these types of facilities relative to that of alternative types of testing is intended to be made in Phase III of this study. 
In order to determine the desired characteristics of a national earthquake engineering experimental facility, it was essential first to identify the types of tests needed and then to determine the capabilities of the facility needed to perform the required tests. The characteristics of reaction walls and shaking tables needed in a central facility were based on the testing needs identified in each area considered. The characteristics are summarized in Tables 2 and 3 . It is important to note that current U.S. facilities are inadequate for almost all the tests recommended.

A primary objective of the first phase of the study was to develop a three- to five-year program of testing for a national experimental research facility. It is impossible at this time to specify an exact order in which tests should be conducted. Priorities established at this time would almost certainly change prior to completion of construction of a large facility. It is therefore appropriate to set forth a general series of tests. The most important test in each of the five areas of interest (those listed first in each category) should be considered to have equal priority. These tests make up the initial program of testing. The total effort required to conduct these tests, based on the estimates of time required shown in Appendix D, will be 25 project-years. This represents a realistic schedule of testing for the first five years of operation of a large facility. 
TABLE 1

SUMMARY OF EXPERIMENTAL NEEDS

\begin{tabular}{|c|c|}
\hline $\begin{array}{l}\text { STRUCTURE } \\
\text { CATEGORY }\end{array}$ & PRIMARY EXPERIMENTAL NEEDS \\
\hline $\begin{array}{l}\text { Low-rise } \\
\text { Structures }\end{array}$ & $\begin{array}{l}\text { Tilt-up Construction } \\
\text { Wood-frame Residential structures } \\
\text { Cavity-wall Masonry Structures } \\
\text { Light Metal Frame Office Buildings } \\
\text { Mobile Home Anchorage Systems }\end{array}$ \\
\hline $\begin{array}{l}\text { Medium-rise } \\
\text { Structures }\end{array}$ & $\begin{array}{l}\text { Concrete Moment-frame structures } \\
\text { Steel Moment-frame Structures } \\
\text { Structures with Base Isolation } \\
\text { Structure with Soft story } \\
\text { Non-structural Components } \\
\text { Precast Bearing Wall Structures } \\
\text { Steel stud and Gypsum Board Walls }\end{array}$ \\
\hline $\begin{array}{l}\text { High-rise } \\
\text { Structures }\end{array}$ & $\begin{array}{l}\text { Frame Tube structures } \\
\text { Energy-dissipating Devices } \\
\text { Components of Dual Structural systems }\end{array}$ \\
\hline $\begin{array}{l}\text { Industrial } \\
\text { Processing } \\
\text { Facilities }\end{array}$ & $\begin{array}{l}\text { Unanchored Liquid-filled Tanks } \\
\text { Methods of Retrofit for Existing } \\
\text { Industrial Facilities } \\
\text { Chemical Plant and Refinery Equipment }\end{array}$ \\
\hline $\begin{array}{l}\text { Power } \\
\text { Facilities }\end{array}$ & $\begin{array}{l}\text { Components of Power Plants } \\
\text { Certification Tests of Components of Electrical } \\
\text { Distribution Facilities } \\
\text { Soil-Structure Interaction } \\
\text { Electrical Transmission Towers }\end{array}$ \\
\hline
\end{tabular}




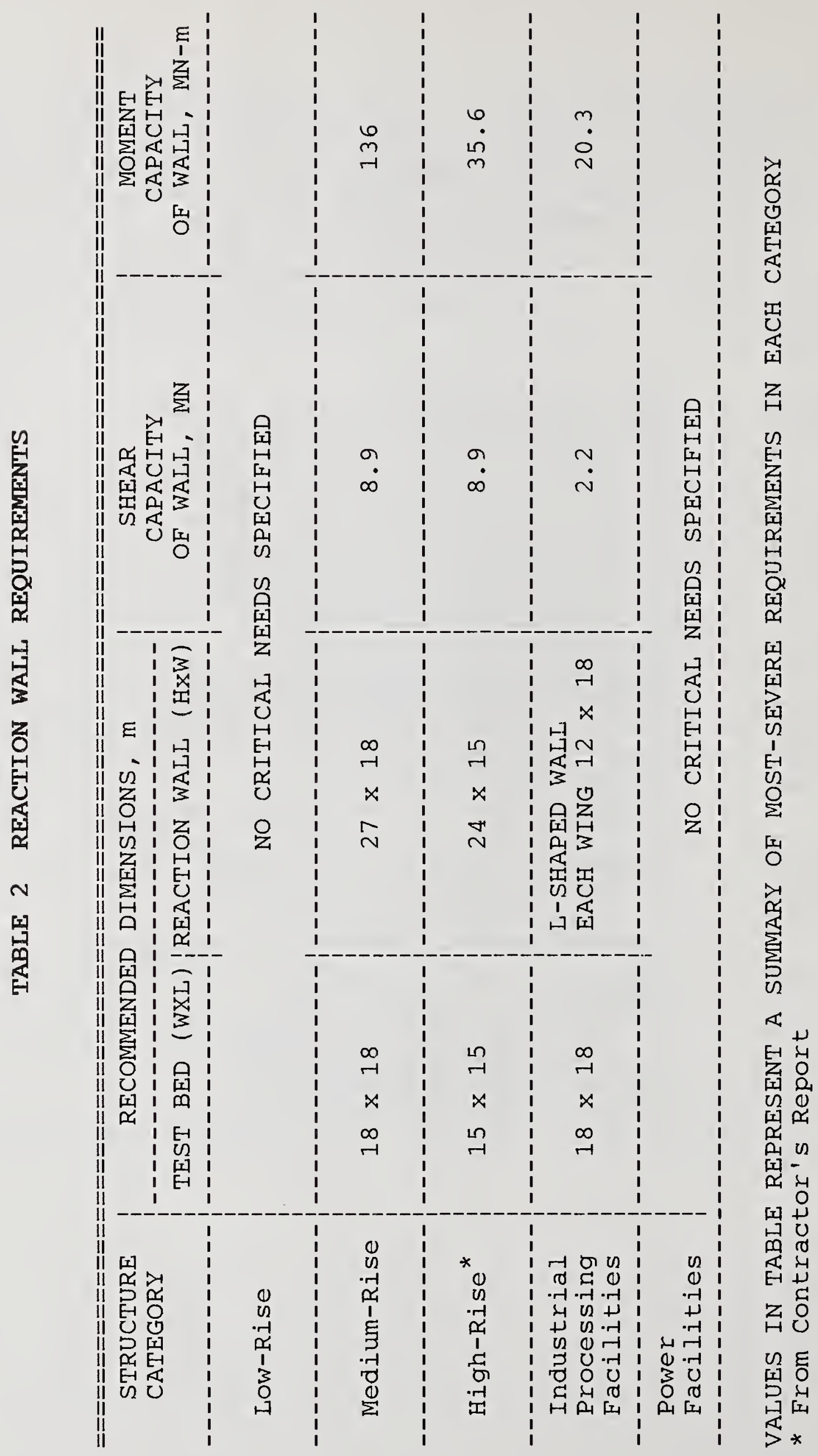




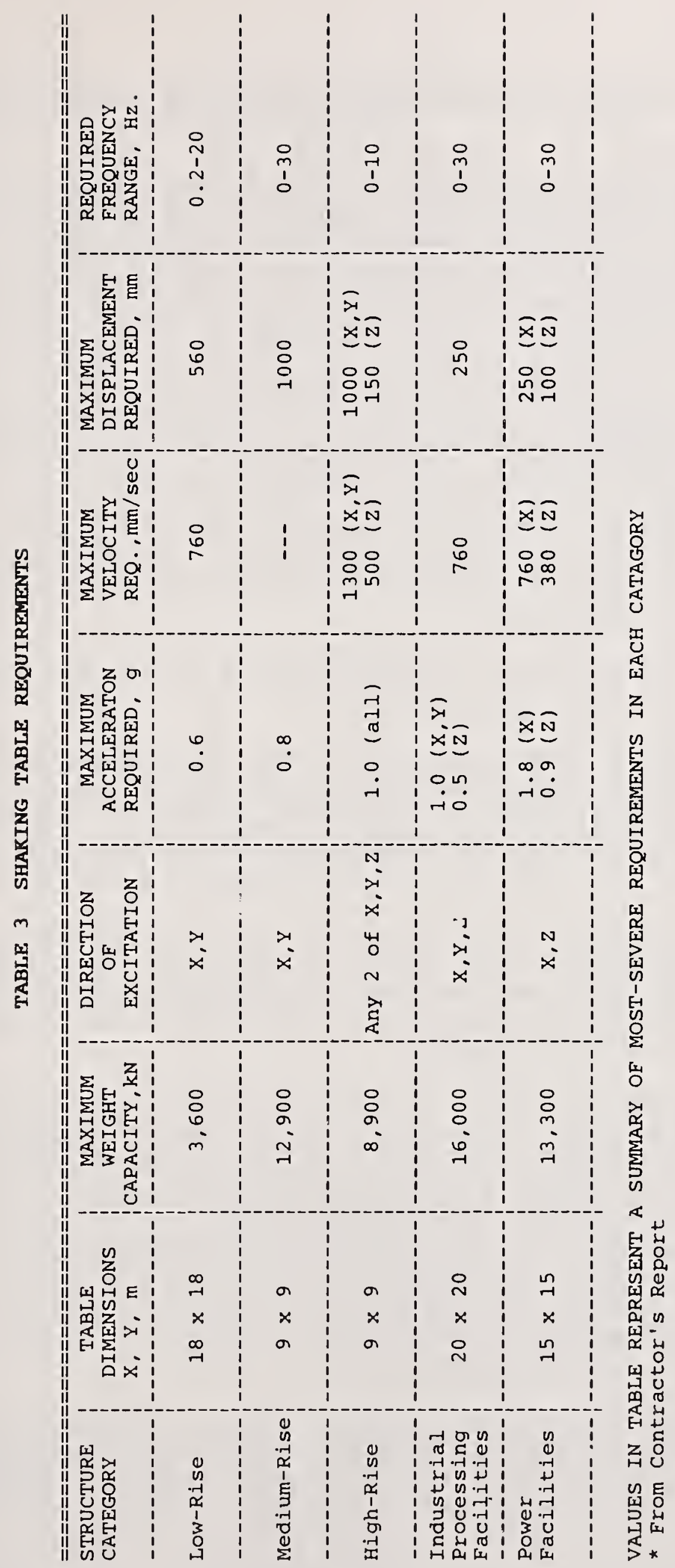




\section{EXISTING FACILITIES FOR LARGE-SCALE TESTING}

In order to evaluate the need for a new earthquake engineering facility capable of conducting large-scale tests, it is important to consider the capabilities of existing facilities in the U.S. and to compare these capabilities to those of facilities in other countries. A summary of existing large-scale testing facilities worldwide is contained in Appendix $B$. The following major points may be noted in this summary:

1. Only approximately twenty percent of the large shaking tables in the world are located in the United states. Almost half the tables in the world, including some of the largest, are located in Japan.

2. Most of the large shaking tables in the world have been built in the last ten years. During this time, twice as many tables of all sizes have been built in Japan as in the U.S.

3. There are no shaking tables in the U.S. having an area greater than $100 \mathrm{~m}^{2}$.

4. More than half of all the reaction walls in the world are located in Japan, and ten of those walls have been classified as large in Appendix B. Fewer than a third of all reaction walls in the world are located in the U.S., and only four of them are large.

It is clear that U.S. facilities are significantly smaller and less sophisticated than those in Japan. It is also clear, as noted in the previous section, that existing U.S. facilities are not large enough to perform the majority of the large-scale tests identified in this report.

Two possibilities for action exist: The United states can upgrade its own facilities to a level comparable to the facilities in Japan, or it can enter into cooperative agreements with groups in Japan to perform needed testing. In this light, it is appropriate to consider the scope of previous and possible future cooperation with research establishments in Japan and in other countries having experimental needs similar to those of the U.S. A discussion of the scope of previous and possible future cooperative research efforts with groups in Japan, Taiwan, and Germany is given in Appendix $C$.

Because facilities already exist in Japan for static and dynamic testing of large structures and other components, the use of Japanese facilities is an alternative to a large capital

investment in a national facility by the U.S. The National 
Research Council ad hoc committee on facilities and instrumentation recognized this fact in their report in 1984 (1), and addressed the issue as follows:

"The Japanese presently have earthquake engineering experimental/test facilities that are substantially larger in scale and more complex in nature than those existing in the United States. Cooperative use of the Japanese facilities by U.S. and Japanese researchers has the potential to offer full-scale data without the need for a large capital investment in the United states."

The committee, however, was also quick to point out that the use of Japanese facilities should not be considered a permanent substitute for a facility housed in the U.S. and capable of responding to specific requests for testing by researchers and industry.

13 


\section{CONCLUSIONS}

During the first phase of a study for a national earthquake engineering experimental facility, conclusions were reached regarding research needs. Twenty-three high-priority tests of large-scale structures and components were identified in five areas. The tests comprise a three- to five-year program of testing.

A comparison of U.S. facilities with those worldwide demonstrated that facilities in the U.S. are less sophisticated and smaller than those in some other countries, particularly Japan. In addition, the facilities available in the U.S. are not large enough to carry out any of the high-priority tests identified.

It was further concluded by workshop participants that the benefits to be gained from the ability to perform such testing warrant continuation of the present four-year study in order to determine how best to perform this testing. Continuation of the study should include detailed determination of the characteristics of a centralized national experimental facility or distributed national facilities and a comparison of relative costs and benefits from testing in a laboratory facility and similar testing conducted by alternative means. siting requirements and a management plan for a national facility should be developed. 


\section{ACKNOWLEDGMENTS}

NBS received assistance from several sources during the planning and conduct of this study. An interagency steering group met frequently throughout the project to evaluate progress and provide direction. This group was chaired by Dr. Arthur J. Zeizel of the Federal Emergency Management Agency and included in its membership Dr. Walter Hays of the United States Geological Survey and Dr. A. J. Eggenberger of the National Science Foundation.

The National Academy of Sciences established an advisory panel for the study under the auspices of the NAS committee on Earthquake Engineering. The panel was chaired by Dr. James E. Beavers and included in its membership Dr. Mirhan S. Agbabian, Dr. Robert D. Hanson, Dr. George W. Housner, Dr. James O. Jirsa, Dr. William F. Marcuson, and Dr. Joseph Penzien. Dr. Riley M. Chung of the National Research Council staff provided administrative support for the panel and also provided valuable input to the interagency steering group.

The following six professional engineering firms were engaged to provide independent evaluations of research needs in the six areas of interest: Wiss, Janney, Elstner Associates, lowrise buildings (5); Henry J. Degenkolb and Associates, mediumrise buildings (6); Skidmore, Owings \& Merrill, high-rise buildings (7); URS Corporation, industrial process facilities (8); John A. Stevenson and Associates, power facilities (9); and Imbsen and Associates, Iifelines (10). These firms identified research needs that served as the basis for the final recommendations developed at the workshop. The success of the workshop itself was due to the enthusiastic participation of all attendees.

Dr. Joseph Reynen from the Commission of European Communities was extremely helpful in providing information on the Commission's study of European needs for a large-scale testing facility. Dr. Toshio Iwasaki, Director of the Earthquake Disaster Prevention Department of the Public Works Research Institute in Tsukuba, Japan, conducted the background study of current utilization of Japanese large-scale testing facilities. Their assistance is gratefully acknowledged. 


\section{REFERENCES}

1. Ad Hoc Committee on Earthquake Engineering Facilities and Instrumentation, Commission on Engineering and Technical Systems, National Research Council, Earthquake Engineering Facilities and Instrumentation, National Academy Press, Washington, D. C., 1984.

2. National Earthquake Hazards Reduction Program Five-Year Plan, Fiscal Years 1985-89, Federal Emergency Management Agency, United States Geological Survey, National Science Foundation, National Bureau of Standards, December, 1984.

3. "Interagency Agreement Between the National Bureau of Standards and the Federal Emergency Management AgencyNational Earthquake Engineering Facility Planning Study," Interagency Agreement No. EMW-85-E-2134, FEMA, Washington, D. C., September 6, 1985 .

4. Scribner, C. F., and Leyendecker, E. V., "Plan for a Design Study for a National Earthquake Engineering Experimental Facility," NBSIR 86-3453, U. S. Department of Commerce, National Bureau of Standards, October, 1986.

5. Freeman, Sigmund A., "Study of Needs for National Earthquake Engineering Experimental Facility for Low-rise Buildings," Wiss, Janney, Elstner Associates, Inc., February 17, 1987 (unpublished report), $14 \mathrm{pp}$.

6. "Determination of Research Needs and Priorities for National Earthquake Engineering Experimental Facility - Large-Scale Testing - Moderate Height Buildings," H. J. Degenkolb Associates, Engineers, September 30, 1986 (unpublished report), $290 \mathrm{pp}$.

7. Elnimeiri, M., "A Report Identifying the Current and Future structural systems for High-Rise Buildings and specifying the Seismic Research Needs Utilizing Large-scale Testing Facility," Skidmore, Owings \& Merrill, October 30, 1986 (unpublished report), $63 \mathrm{pp}$.

8. Larder, R. A., "Experimental Research Needs for Improving Seismic Resistant Design of Industrial Process Facilities," URS Corporation, November 1986 (unpublished report), 46 pp.

9. Stevenson, J. A., "A Report Identifying and Describing the Needs for Seismic Research Utilizing Large or Full Scale Testing of Power Facility structures and Equipment," Stevenson and Associates, Inc., September 30, 1986 (unpublished report), $66 \mathrm{pp}$. 
10. Imbsen, R. A., "A Report Identifying and Describing the Needs for Seismic Research Utilizing Large or Full Scale Testing of Lifeline Facility structures and Equipment," Imbsen and Associates Inc., January 14, 1987 (unpublished report), $42 \mathrm{pp}$. 


\section{APPENDIX A \\ SUMMARY OF PREVIOUS WORKSHOPS}

The benefits to researchers, designers, contractors, and manufacturers from the availability of a facility capable of subjecting large structural models or structural or mechanical components to simulated seismic loading have long been recognized. A number of workshops have been held to consider various types of facilities and the ways they could be of benefit. The following discussion summarizes relevant details of the recent workshops.

1. Potential Utilization of the NASA/George C. Marshall Space Flight center in Earthquake Engineering Research, Earthquake Engineering Research Institute Report, December 1979 .

A site visit and workshop were held at the National Aeronautics and space Administration (NASA) facilities at The George C. Marshall space Flight Center (MSFC), Alabama, on February 22-24, 1979. The workshop was sponsored by NSF and NASA and chaired by members of the Earthquake Engineering Research Institute (EERI). Twenty-six earthquake specialists from academia, industry, and government attended the workshop.

The thrust of the workshop was to examine the feasibility of using the unique MSFC facilities for large-scale seismic testing of both structures and soils. Suggested potential uses were cyclic static and dynamic testing of multistory structures, medium- and large-scale soil model tests to study dynamic behavior of soil masses under earthquake excitation, dynamic soil-structure interaction tests, and utilization of the NASA spacelab under near-zero-gravity environment to evaluate constitutive properties of soils under near-zero confining stress conditions. Cost data were not available to conduct cost analyses relative to any specific test requirements.

An assessment was made of the needs for and availability of large- and full-scale testing facilities in the following areas:

Cyclic static Tests Test towers are needed to apply static cyclic horizontal loads in two directions with forces sufficiently large to test $30-\mathrm{m}$ high (10 stories), 1000-ton specimens to destruction. Available facilities (the University of California at Berkeley, the PCA laboratory and the University of Texas at Austin) do not meet simultaneously these size and force requirements. A number of MSFC facilities that seem to meet these specifications should be considered. These include static and vibration test equipment in the structures and 
Mechanics Laboratory, the structural test tower, the vertical ground vibration facility, the hazardous structures test facility, and the model special test equipment.

Shaking Table A large (15 $\mathrm{m} \times 15 \mathrm{~m})$ shaking table with a payload capacity of 2000 tons and two-directional horizontal motion is needed to perform destructive testing of full-scale (10-story, 1-bay) structural or soil-structure models. The table would be required to have a $500 \mathrm{~mm}$ stroke, a frequency range of 0 to $40 \mathrm{~Hz}$, and a maximum velocity of $65 \mathrm{~cm} / \mathrm{sec}$ for each direction of horizontal motion. None of the available shaking tables meet these specifications. Shaking tables at the University of California at Berkeley, the PCA laboratory and NASA/MSFC are being used for testing small- or medium-scale models or 1 to 2-story, 1-bay large- or full-scale models.

Vibration Generator Sinusoidal vibration generators have been used to measure elastic, dynamic characteristics of large structures. The DOE generator at the Nevada test site and the NASA/MSFC facility (40 shakers, a 45-ton maximum payload and a maximum stroke of $225-\mathrm{mm}$ ) can be used to evaluate the dynamic properties of models or systems in the elastic range. A larger facility will be required to study the changing behavior of large-scale specimens in the inelastic range.

Dynamic Soil Tests The properties of soils sought are the dynamic moduli, Poisson's ratio, and liquefaction parameters. Methods used in the laboratory are the ultrasonic pulse test (to measure compression and shear waves), cyclic triaxial, direct -near and torsional shear tests to evaluate settlement and liquefaction potential, and centrifugal tests to simulate dynamic excitation. Field tests used for in-situ measurements of soil properties include seismic crosshole survey, seismic downhole survey, seismic reflection survey, electrical sensing probe, standard penetration test and horizontal polarized shear wave technique. The NASA/MSFC facilities that can be considered for soil testing include the equipment in the geotechnical laboratory for conducting static, steady-state and threedimensional dynamic testing, and the $3.6 \mathrm{~m}$-diameter centrifuge for simulating dynamic excitation. As noted before, the NASA spacelab was considered for use in soil experiments because it offered the possibility of evaluating key soil parameters without the confinement of a gravitational field.

It was concluded at the workshop that NASA/MSFC did have certain unique testing capabilities for seismic experiments. It was recommended that structural and geotechnical task committees be formed to develop large-scale test programs, taking into account priorities dictated by cost analyses of required modifications and by the unique aspects of the NASA/MSFC facilities. 
2. Experimental Research Needs for Improving EarthquakeResistant Design of Buildings, EERI Report No. 84-01, January, 1984 .

This workshop was held on July 21-22, 1983 and was hosted by the Earthquake Engineering Research Institute (EERI). The purpose was to identify experimental research needs. It was sponsored by NSF and was attended by participants from academia, the private sector and the U.S. Government. The workshop focused on the following subjects:

Identification of Experimental Research Needs There was general consensus on the inadequacy of existing information on the inelastic performance of buildings in severe earthquakes. Research to determine experimentally the ultimate capacity of building systems as well as their capacity to sustain damage without failure or collapse were underscored. Important types of buildings for which full-scale tests are needed were identified. Low- to high-rise residential buildings as well as medium- to low-height commercial and industrial structures were considered. An economic analysis indicated that $\$ 20 \mathrm{million}$ would be required to determine the performance of just one major type of structure. Recommendations on specific details of needed experiments were not included.

Evaluation of Experimental Methods Specific shaking table needs were cited: a $25 \mathrm{ft} \times 50 \mathrm{ft}$ table having one horizontal degree of freedom; a table similar to the one located at the University of California at Berkeley but having two horizontal components of motion (instead of one vertical and one horizontal as at Berkeley); and a table large enough to test at least small structures at full scale.

It was recommended that two to three reaction wall systems be constructed, all with the capacity to apply force in three directions, and one with capacity to test structures with heights of at least $40 \mathrm{ft}$.

Requirements were identified and specifications given for a shaking table capable of applying motion in three orthogonal directions for testing small (one-quarter-scale or less) models. Some guidance was provided on the cost of construction and maintenance of such a facility.

Harmonic excitation, ambient testing and impulse loading were explored for testing of prototype structures. However, it was concluded that such tests could not take the central role in experimental research because of costs in time and money.

Two excitation methods using buried and contained high explosives for testing large soil-structure systems were discussed. These methods were considered as basic tools for 
earthquake experimental research because of their potential for use in evaluating the inelastic response of large structures and soil-structure systems. Cost was estimated at $\$ 900 \mathrm{~K}$ for testing using contained explosives. The cost of testing large structures to damaging levels was estimated to be $\$ 5$ million.

Feedback from the response of instrumented buildings was considered to be key information for mathematical modelling. Therefore, it was recommended that instrumentation of existing buildings be part of a national plan for earthquake hazard mitigation. However, it was recognized that the randomness and infrequency of occurrences of strong-motion earthquakes remain a major limitation of this form of experimental research.

The workshop advanced the concept of a research consortium to coordinate all the experimental research in the U.S., and proposed a specific management plan involving sponsors, industry, universities, research institutions, the laboratory manager, and other directors, operators, and users of the laboratory.

Existing U.S. facilities were identified relative to research needs. Plans to provide new and/or expanded facilities were proposed, including modernization of existing facilities and establishment of a major national facility which would house a large $(20 \mathrm{~m} \times 20 \mathrm{~m})$ shaking table.

3. A National Bridge Engineering Laboratory - A Proposed Plan, Center for Civil Engineering Earthquake Research (CCEER), College of Engineering, University of Nevada, Reno, December, 1984 .

This report documents the proceedings of a workshop to identify earthquake research and experimental facilities needs for bridges. The workshop was sponsored by NSF and held in Reno, Nevada, on April 4-6, 1984. The participating engineering professionals were drawn from private practice, academia, and state and federal organizations. The principal topics discussed were the highway bridge problem, the solution of this problem through establishment of a National Bridge Engineering Laboratory, research needs, and laboratory management.

National Bridge Engineering Laboratory on the basis of perceived needs for research, participants in the workshop recommended the following:

* A national center for bridge engineering to promote excellence in bridge engineering, and particularly to promote excellence in design for seismic loading. 
* The center should be equipped with experimental facilities for testing large- and full-scale bridges, both in the laboratory and in the field. It should also provide education, training and information services to the bridge engineering community.

The needed equipment and facilities were illustrated in ten conceptual drawings. The capital costs for the center were estimated to be approximately $\$ 100-150$ million, including land acquisitions, buildings and equipment. The expenditures for operations and research activities were estimated at $\$ 20$ million per year.

Research Needs A broad spectrum of experimental research was identified. Areas in which tests were recommended included large-scale experiments on multiple shaking tables, large-scale experiments using the pseudo-dynamic method, field experiments on full-size bridges, and repair and retrofit methods for existing bridges.

Laboratory Management Three aspects of management of the facility were considered during the workshop. The recommendations developed were that the laboratory should:

* be managed by a board of directors made up of representatives from all elements of the bridge engineering community

* have a managing director

* have a permanent, high-level, professional and technical staff

The management structure proposed was similar to that suggested for the earthquake engineering laboratory proposed during the EERI workshop of July, 1983. 


\section{APPENDIX B \\ SURVEY OF FACILITIES WORLDWIDE}

The two most common types of laboratory facilities used in seismic testing today are 1) shaking tables, and 2) reaction walls. This section discusses the capabilities of existing facilities of these two types in the United states and other countries.

\section{SHAKING TABLES}

The graphs shown in figures 1 through 6 illustrate information obtained from References $1-5$ and present different components of a shaking table's performance.

As illustrated in figure 1, more than half (fifty-two percent) of the seventy-nine shaking tables existing worldwide have an area less than or equal to 10 square meters. Twentynine of these, or thirty-seven percent of all such tables worldwide, are located in the United states.

of those shaking tables with an area greater than 10 square meters, only seven are located in the United states. Three of these have an area between eleven and fifteen square meters. The largest electro-hydraulic shaking table in the United states is located at the Earthquake Engineering Research center at the University of California at Berkeley and has a table area of 37.2 square meters. Shaking tables with areas greater than 100 square meters include tables at the Institute for Building Research in Romania, at the Nuclear Power Engineering Test Center in Japan, and at the National Research Center for Disaster Prevention in Japan. The world's largest table has an area of 900 square meters and is located in the USSR.

Figure 2 summarizes information about the location of large (defined here as having a table larger than 3 meters by 3 meters) shaking tables. Of the forty-seven large shaking tables worldwide, twenty-four (approximately one-half of the total) are located in Japan, nine (less than one quarter of the total) are in the United states, four are in Germany and the rest are located in those countries with two tables or less. Also worth noting in figure 2 is the category "OTHER," in which are included those countries with fewer than three large tables each. The countries with two large tables are china, USSR, Romania and Italy. Those with only one large table include France, Yugoslavia and Greece.

The time of installation of all large shaking tables is illustrated in figure 3 . The majority (twenty-five) of all large shaking tables worldwide have been installed during the last 10 
years (1976-1986), and most of those are located in Japan. Only four tables were installed in the United states during this period, while eleven were installed in Japan. The largest table installed in the United states during this period (at Wyle Laboratory) has an area of 33.6 square meters.

A comparison of displacement capacities of existing shaking tables is shown in figure 4. This figure illustrates the fact that the total maximum displacement of the table in any direction of motion for slightly more than half (fifty-three percent) of all existing shaking tables is less than $100 \mathrm{~mm}$. Seventy-four percent of the shaking tables in Japan (a total of twenty-four) are in this category. Thirty-eight percent of the shaking tables in the United states (a total of twenty-nine) have a similar displacement capacity. Seventy-two percent of all existing tables have a capacity for maximum displacement in any direction of motion of less than $150 \mathrm{~mm}$ (approximately 6 inches). Of the twenty-one shaking tables with capacities for maximum displacement greater than $150 \mathrm{~mm}$, eleven would be considered large by the definition given previously. Eight of these large tables are located in the United states, two are located in Japan, and one is in the USSR.

Figure 5 illustrates the distribution of horizontal acceleration capacities (assuming the table to be loaded with maximum weight) of existing shaking tables. Almost all of the tables having the capacity to apply accelerations greater than $10 \mathrm{~g}$ are located in the United States. Eighteen of the twenty tables capable of applying accelerations greater than $5 \mathrm{~g}$ are located in the United states. However, these shaking tables are too small (having table areas less than 3 meters by 3 meters) to use for seismic testing of full-scale structures. Shaking tables capable of applying accelerations less than $2 \mathrm{~g}$ comprise sixtyone percent of all existing tables. Seventy-three percent (nineteen out of twenty-six) of all Japanese shaking tables can apply a maximum of $1.0 \mathrm{~g}$ horizontal acceleration. Six tables located in Japan and four tables located in the U.S. are capable of applying maximum accelerations between $1.1 \mathrm{~g}$ and $2.0 \mathrm{~g}$. These ten tables all could be used to conduct large-scale seismic tests.

The distribution of weight capacities of existing tables is shown in figure 6 . Twenty-four shaking tables, or approximately thirty percent of those existing, are capable of carrying the weight of a full-scale structure (200 kN or greater). Three tables having a capacity greater than $200 \mathrm{kN}$ are located in the Unites states (at the University of California at Berkeley, Union Carbide, and Wyle Laboratories). Thirteen, or approximately onehalf of all shaking tables with weight capacities greater than $200 \mathrm{kN}$ are in operation in Japan, two are in the USSR, and two are in Romania. 
Shaking table testing of full-scale structures requires a table which has sufficient size, acceleration capacity, and weight and displacement capacity. As noted above, only twentyfour existing tables have a weight capacity of at least $200 \mathrm{kN}$. All of these tables can apply lateral accelerations of at least $1.0 \mathrm{~g}$ when loaded to their capacities. If it is also required that the minimum area of the table be 25 square meters, only approximately twenty-four percent of all existing tables meet weight capacity, acceleration capacity, and area criteria. Some other tables meet one or more, but not all, of these criteria. of the seventy-nine shaking tables existing worldwide, more than half are limited to testing of small-scale models.

\section{LARGE REACTION WALLS}

The use of reaction walls to apply static lateral loads is perhaps the most common method of seismic testing used throughout the world. Reaction walls are defined here as large if they are greater than 10 meters high. In this section, large reaction walls will be discussed and information about these walls will be illustrated in figures $7-9$.

Figure 7 illustrates the fact that more than twice as many large reaction walls are located in Japan as in the United states. There are a total of forty-seven reaction walls worldwide. Twenty-five of these walls, including ten walls more than ten meters tall, are located in Japan. Fifteen reaction walls are located in the U.S., but only four of these are taller than 10 meters.

Figure 8 illustrates the distribution of lateral shear capacities of all existing reaction walls. Sixty-three percent of existing walls have a lateral shear capacity less than or equal to $10 \mathrm{MN}$. Of these, eleven walls are located in the United states, thirteen are in Japan, three are in Australia and one is in South Africa. Twenty-nine reaction walls, or sixty-one percent of all reaction walls, have a shear capacity greater than $6 \mathrm{MN}$. Of these, six are in the United states and twenty-two are in Japan.

Seven of the twenty-two large reaction walls (greater than 10 meters high) located in Japan have a shear capacity greater than $6 \mathrm{MN}$. Two of the six large walls in the United States have lateral shear capacities greater than 6 MN. There are no walls outside of Japan that are both higher than 10 meters and have a lateral shear capacity greater than 11 MN.

The Portland Cement Association (U.S.) has two of the largest and strongest reaction walls in the world, although both walls are less than 10 meters high. The Building Research Institute (Japan) has one of the strongest and highest reaction walls in the world. 
Figure 9 summarizes information about the bending capacity of reaction walls worldwide. Thirty-four percent of all existing reaction walls have bending capacities less than or equal to 10 MN-m. Nine of the fifteen walls in the United states have capacities in this range. Of all walls higher than 10 meters and having bending capacities greater than $50 \mathrm{MN}-\mathrm{m}$, two are located in the United States and five are located in Japan.

of the ten walls in Japan higher than 10 meters, all have a bending capacity of at least $11 \mathrm{MN}-\mathrm{m}$. The reaction walls which have bending capacities greater than $50 \mathrm{MN}-\mathrm{m}$ and which are located in the United States include the walls at PCA (2), the National Bureau of Standards, and the Budd Corporation. The reaction walls located in Japan having capacities greater than 50 MN-m are the walls at the sumitomo corporation, the ohbayashi Corporation, the Fujita Corporation, the okumura corporation, the Toda Institute, and at the Building Research Institute (2). There are no large reaction walls outside of Japan or the United states. 


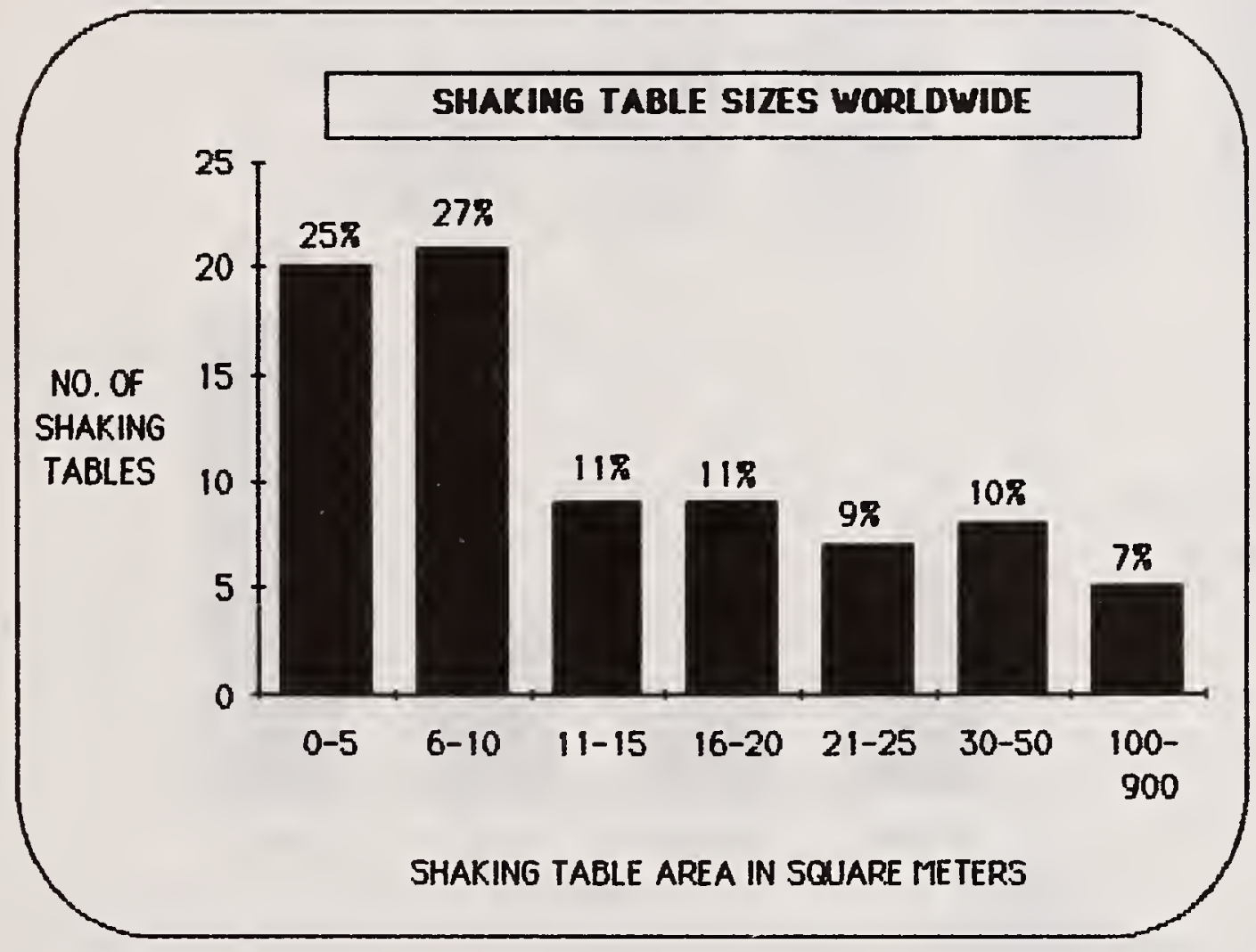

Figure 1. Sizes of shaking tables worldwide. 


\section{TOTAL MUMBER OF LARGE* SHAKIMG \\ TABLES PER COUNTRY}

NO. OF SHAKING

TABLES

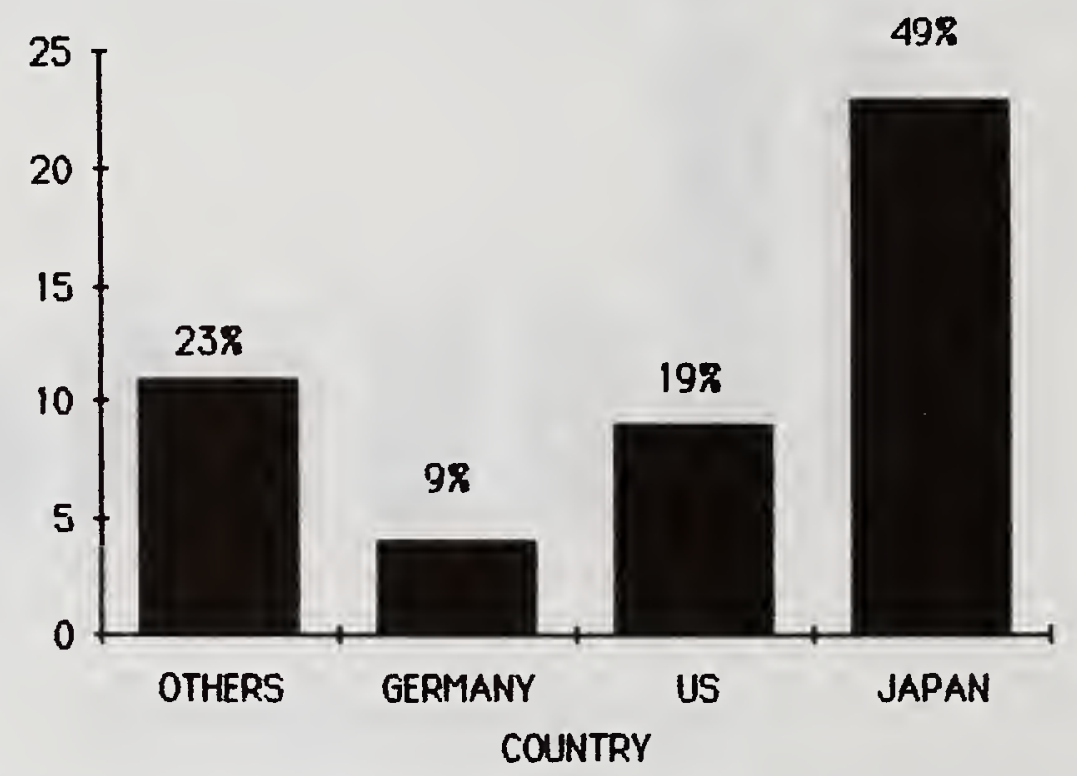

* TABLES $>3 \mathrm{~m} \times 3 \mathrm{~m}$

Figure 2. Location of large shaking tables. 

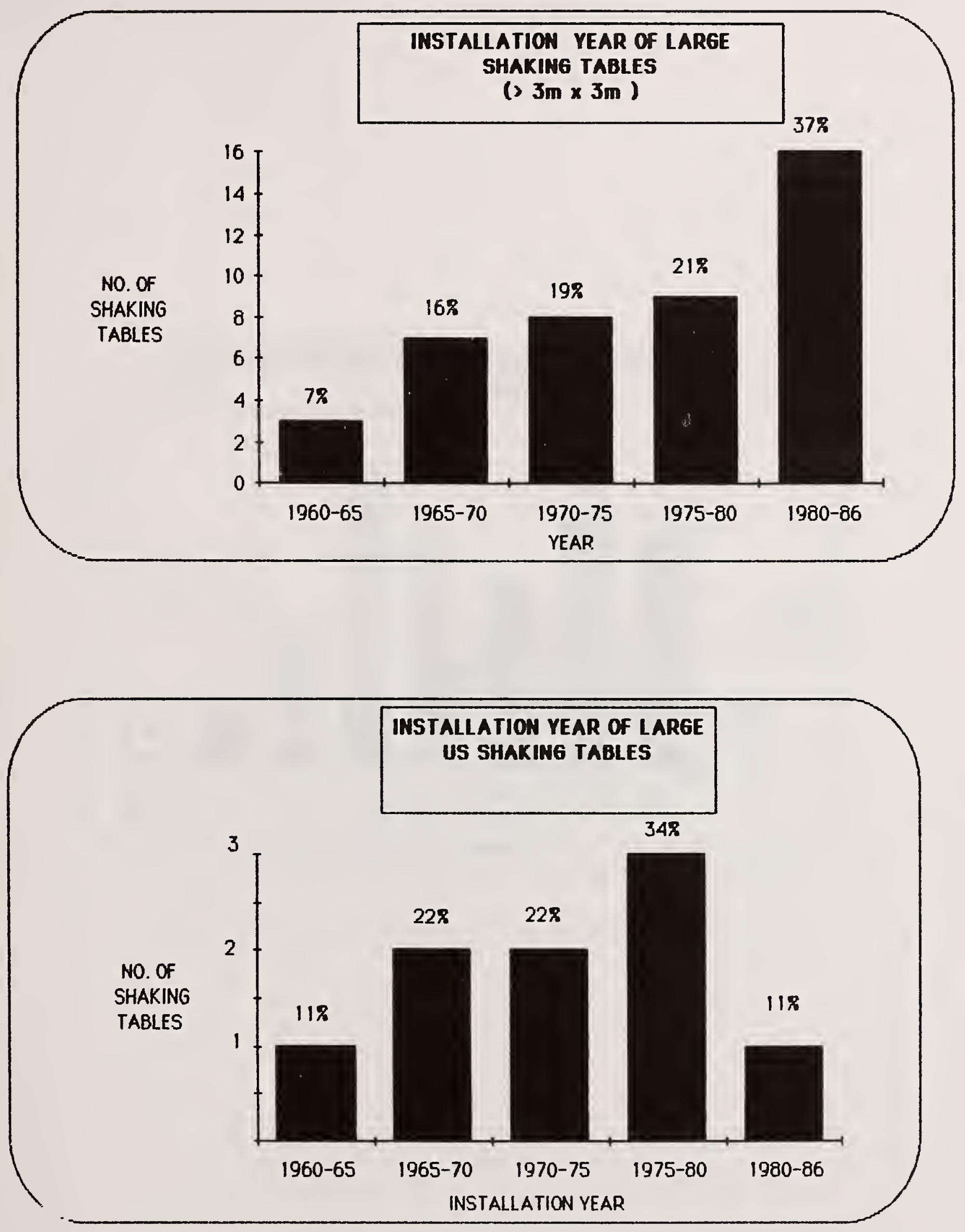

Figure 3. Year of installation of large shaking tables. 


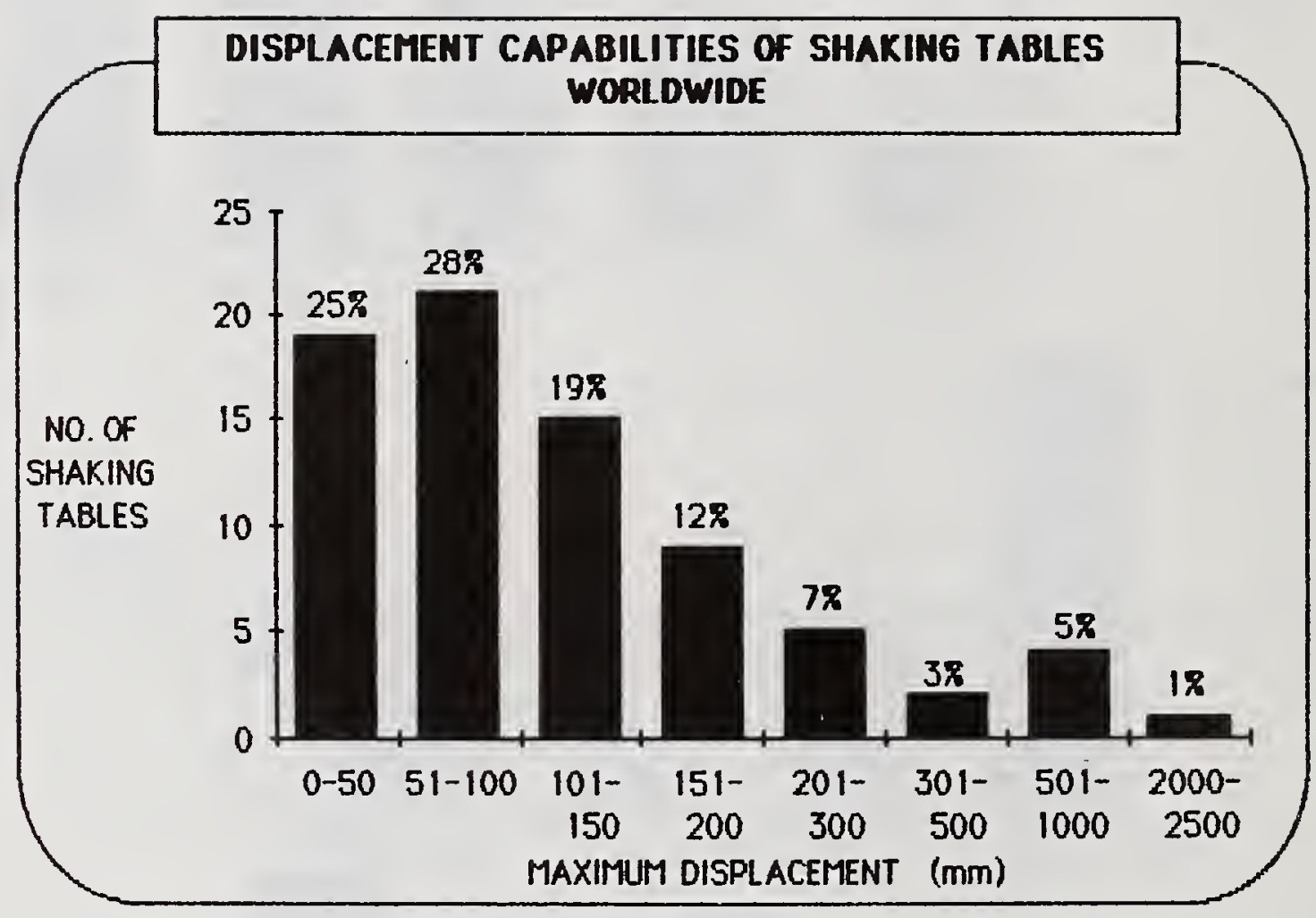

Figure 4. Displacement capacities of shaking tables. 


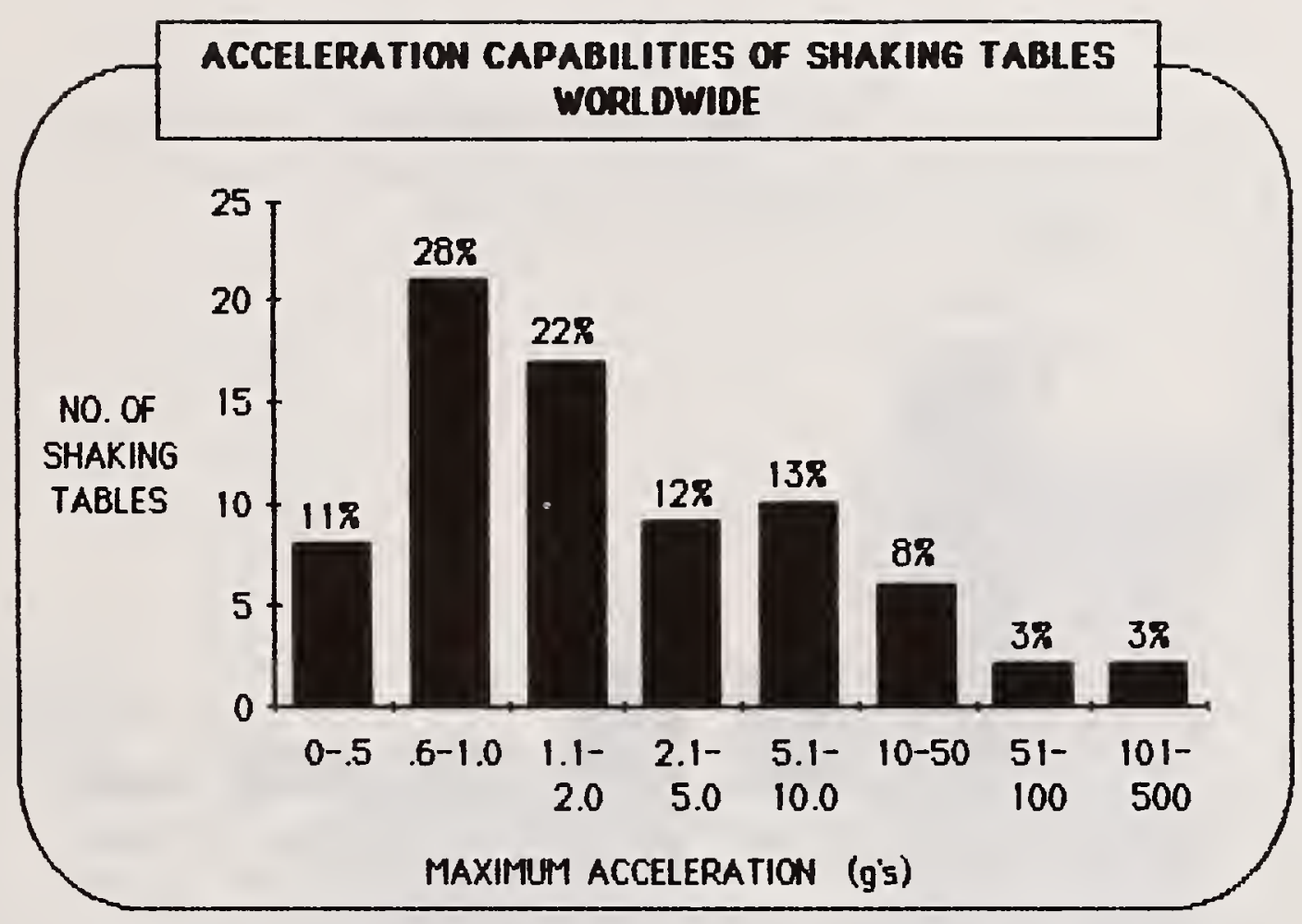

Figure 5. Acceleration capacities of shaking tables. 


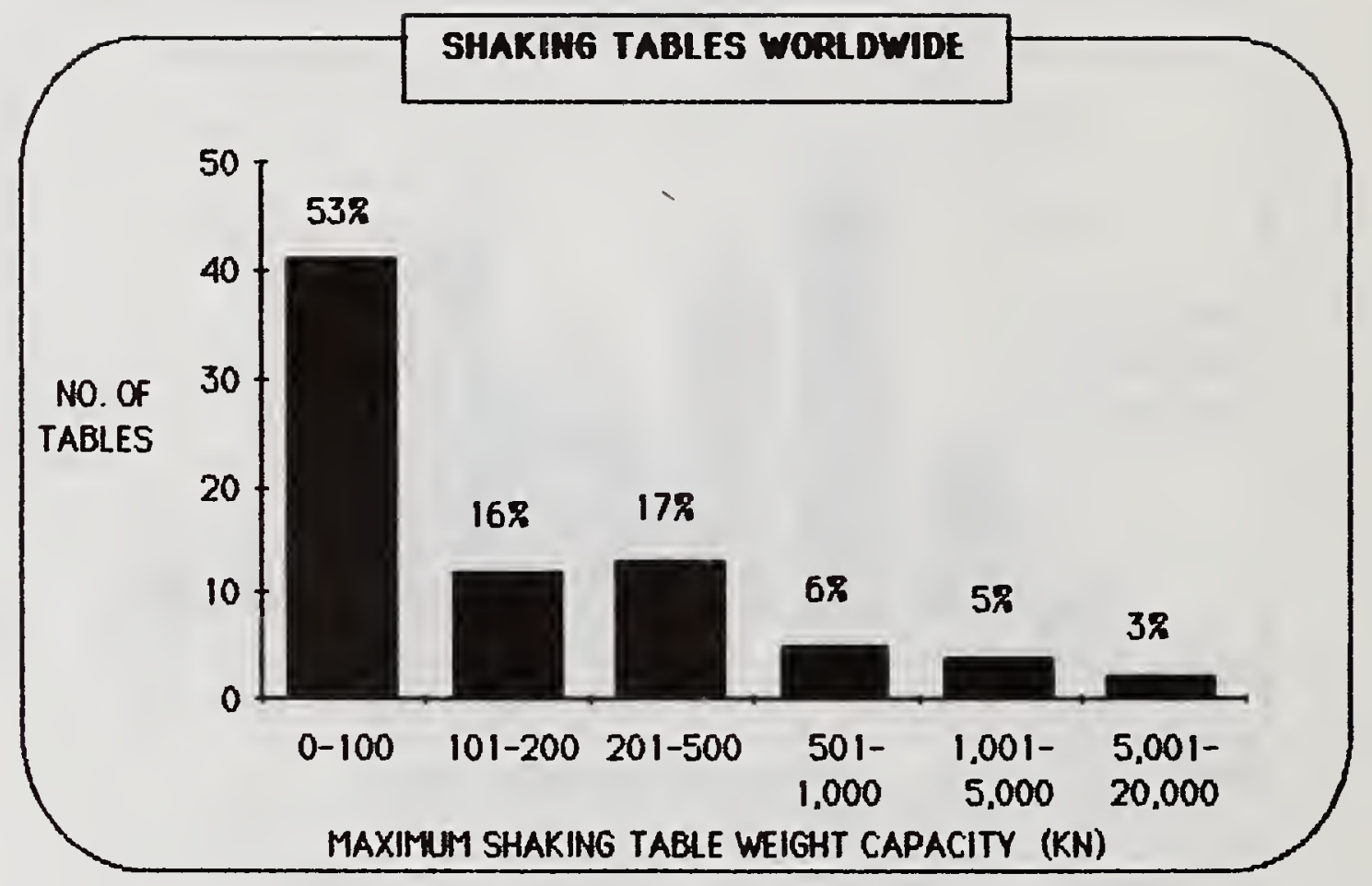

Figure 6. Weight capacities of shaking tables. 


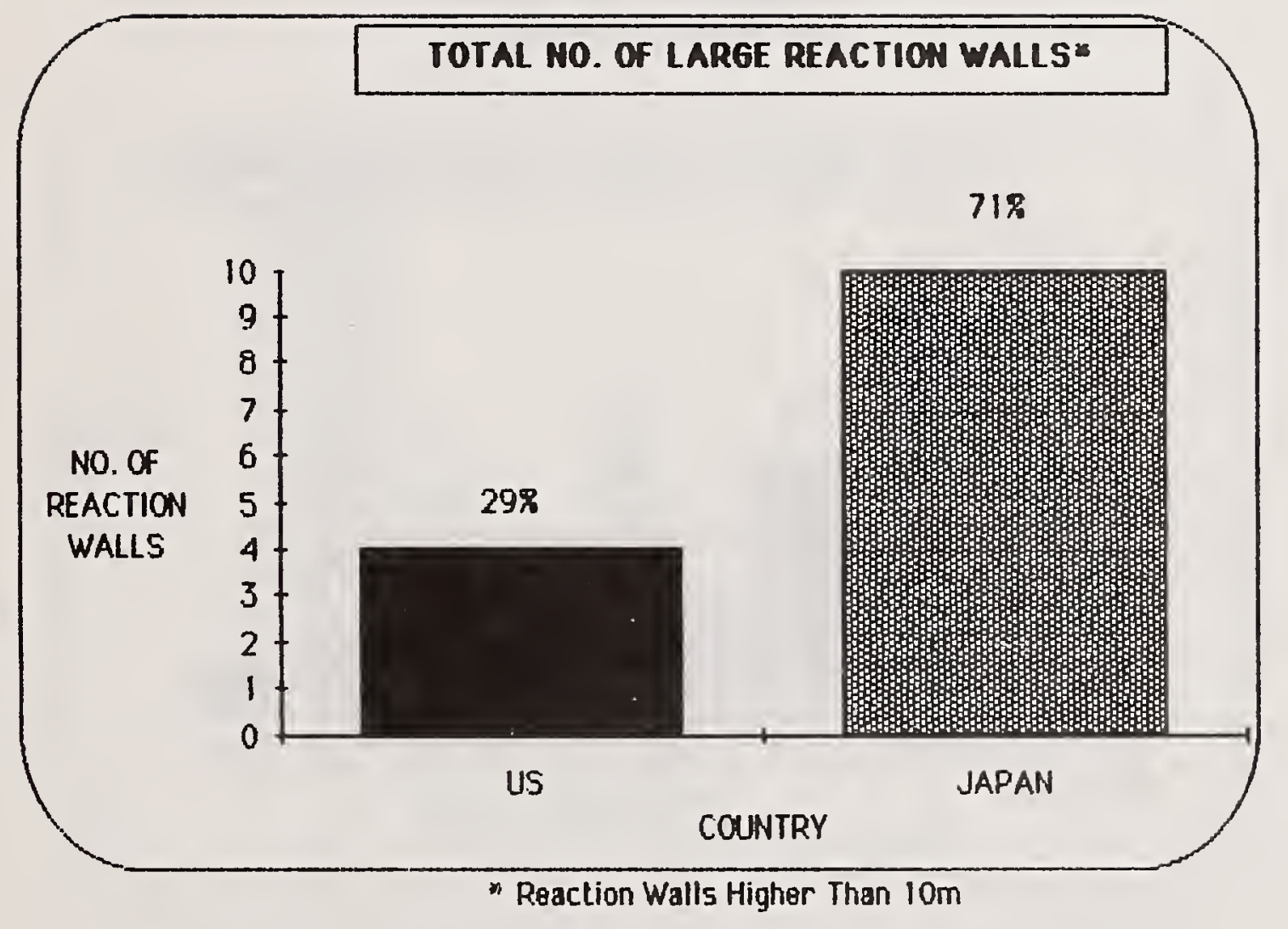

Figure 7. Distribution of large reaction walls. 


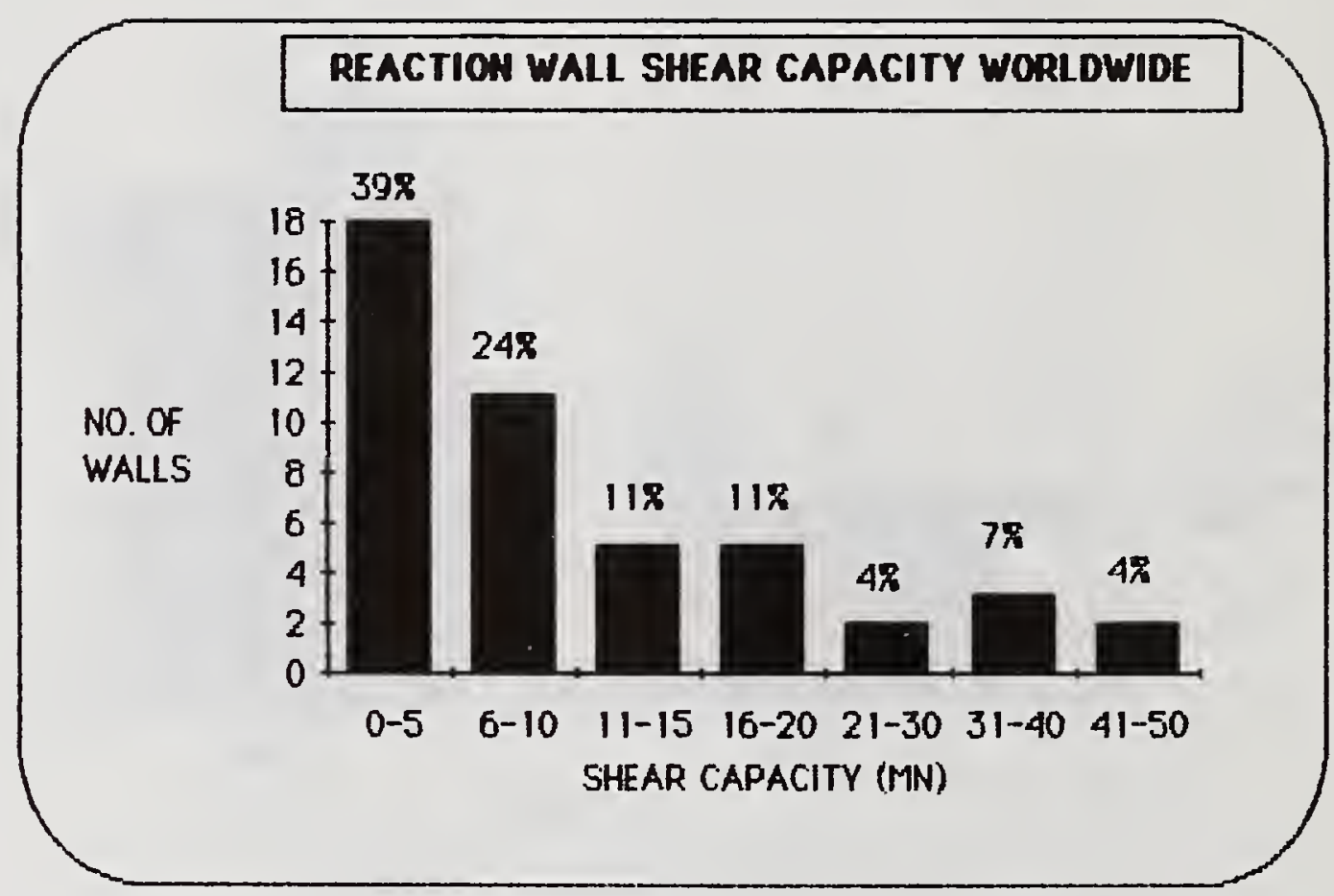

Figure 8 . Shear capacities of reaction walls. 


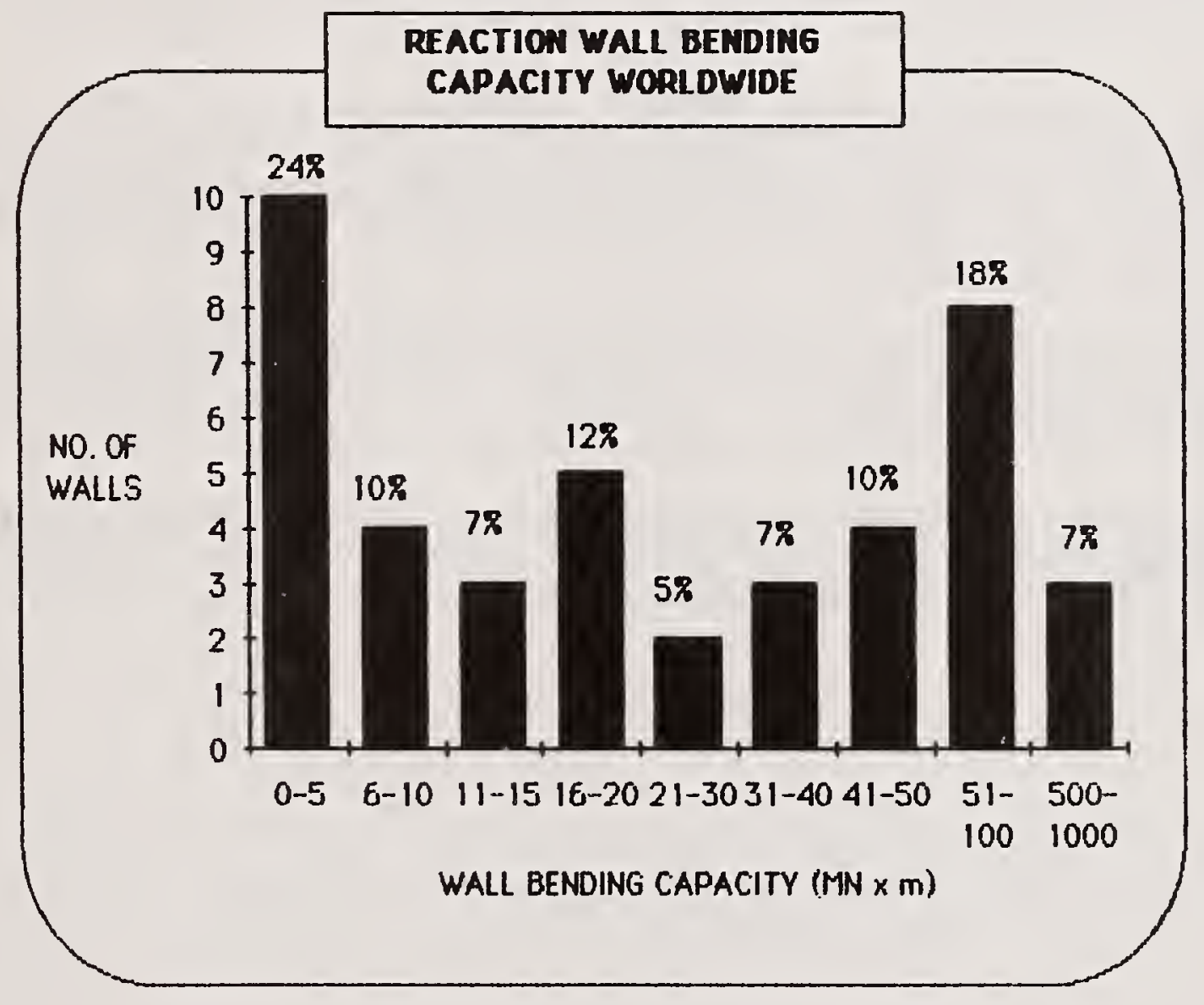

Figure 9. Bending capacities of reaction walls. 


\section{REFERENCES - APPENDIX B}

1. "Experimental Research Needs for Improving EarthquakeResistant Design of Buildings", EERI Report No. 84-01, Earthquake Engineering Research Institute, Berkeley, California, January, 1984.

2. Kamimura, K., Aoki, Y., and Masayoshi, N., "Kenchiku Kenkyu Shiryo", Register of World Large-Scale Test Facilities for Building Research, Report for C. I. B., No. 49, Building Research Institute, Ministry of Construction, Tsukuba, Japan, March, 1984 .

3. "Building Research Institute, Ministry of Construction", a public information report published by the Japanese Ministry of Construction, Tsukuba Science City, Japan, 1981.

4. Stevenson, J. A.,"A Report Identifying and Describing the Needs for Seismic Research Utilizing Large or Full Scale Testing of Power Facility Structures and Equipment", Draft Report for NBS, Stevenson and Associates, Cleveland, Ohio, September, 1986.

5. "Facilities of the National Bureau of Standards", U. S. Department of Commerce, NBS SP 682, Gaithersburg, Maryland, September, 1984 .

6. "Tadotsu Engineering Laboratory", Seismic Proving Tests for Large Components of Nuclear Power Plants, Nuclear Power Engineering Center, MITI, Japan, 1982. 


\section{FACILITIES IN JAPAN}

In the process of considering the needs of the United states engineering community for a large-scale experimental facility, it was important to review programs undertaken by other countries to address their own testing needs. Also of interest was the availability of overseas test facilities for use by U.S. investigators should this approach be deemed appropriate. The information included in this appendix was obtained from a survey of the Japanese seismic testing program and from a review of a recent study conducted to determine the needs for a large testing facility in Europe.

In order to determine the availability of Japanese facilities for use by engineers in the U. S. and in countries outside of Japan, the Public Works Research Institute of Japan was contacted. Dr. Toshio Iwasaki, Director of the Institute's Earthquake Disaster Prevention Department and a member of the U.S.-Japan Cooperative Program in Natural Resources, Panel on Wind and Seismic Effects, provided information about the seismic testing resources of the Japanese government and of Japanese companies that maintain large testing facilities.

The status of large-scale seismic testing facilities in Japan is well documented. A register published in 1984 (Ref. 2, Appendix B) listed the majority of facilities currently existing in Japan and elsewhere. Since that time, three institutions listed in the register have installed either new shaking tables, reaction walls, or testing machines. In addition, some combination of shaking tables, reaction walls, and testing machines have been installed in five institutions that had not been previously listed. The institutions that have upgraded old facilities or installed new facilities are summarized in Table Cl. Characteristics of all new facilities are listed in Tables $\mathrm{C} 2$ and $\mathrm{C} 3$.

The facilities available in Japan have attracted the interest of U. S. Government agencies and private firms having a need for specialized testing. Dr. Iwasaki contacted eighteen public institutions and private firms in Japan to determine the availability of their facilities to U.S. researchers and to determine if U.S. firms have discussed use of the facilities. The results of this inquiry are summarized in Table $\mathrm{C} 4$.

All of the organizations contacted indicated that their facilities could be made available to U.S. Government agencies. Ten of these organizations stated that they would be willing to lease their facilities to American private firms, and all of the 
organizations indicated that they would agree to participate in cooperative research with either private firms or government agencies from the U.S. The majority of Japanese firms are willing to negotiate the fee for use of their facilities, but the majority are also unwilling to allow outside firms more than three months to complete tests for which they lease testing facilities.

\section{STUDY BY EUROPEAN COMMUNITIES}

The number and capacity of facilities available in Japan are unequalled elsewhere in the world. The demonstrated benefits provided by these facilities have inspired engineers in countries other than Japan to investigate their own needs for similar facilities. The Commission of European Communities recently considered needs of European engineers for a large central seismic testing facility. Although the results of their study have not been reported publicly and no decisions have been made to design or construct a large regional testing facility in Europe, the study did contain the following general findings:

* Experimental verification of computer models is necessary to insure accurate idealization of structural properties and accurate prediction of structural behavior, particularly inelastic cyclic behavior.

* Small-scale experimental test facilities have significant limitations. Construction of test specimens is difficult and expensive. Because extensive extrapolation is required to relate behavior of prototype structures to that of model structures, inaccurate representation of nonlinear behavior of prototype structures is possible.

* A majority of engineers of the European community have agreed that their testing needs could be satisfied by a facility containing a large reaction wall and a shaking table with a weight capacity of 200 metric tons.

The study also noted that a factor more important than the construction of specific facilities is coordination of research activities in earthquake engineering and safety of structures through centrally designed and managed research programs.

\section{INTERNATIONAL COOPERATIVE RESEARCH}

one option to undertaking the construction of a national engineering facility is to use facilities in other countries under cooperative testing agreements. Because several facilities appropriate to the needs of some experimentalists in the U.S. 
exist in other countries, the use of these facilities whenever possible could delay the need and expense of construction of a central facility in the U.S.

The National Science Foundation, through the U.S.-Japan Cooperative Program in Natural Resources and the U.S.-Japan Cooperative Earthquake Engineering Research Program, has been a major sponsor of cooperative research between the U.S. and Japan. Through these programs, U.S. researchers have participated in tests of full-scale concrete and steel structures at the Japanese Building Research Institute laboratory in Tsukuba, Japan. cooperative research is continuing with the construction and testing of a full-scale masonry structure.

The U.S. Nuclear Regulatory Commission (NRC) and the Electrical Power Research Institute (EPRI) have also undertaken cooperative research and testing projects with groups in other countries. A brief description of these agreements follows.

One of the most attractive facilities for large-scale testing and seismic research is the Japanese Nuclear Power Engineering Test Center's Tadotsu Engineering Laboratory. The shaking table housed in that facility is designed to subject very large components of nuclear powerplants to simulated seismic loading. In 1986 the U.S. Nuclear Regulatory Commission and the Japanese Ministry of International Trade and Industry (MITI) signed an agreement to conduct cooperative tests of powerplant components. Tests of a pressurized water reactor primary coolant loop are scheduled to begin in 1988. Indications are that MITI and NRC will continue to conduct cooperative testing at the Tadotsu site for the next decade. In addition, it is possible that this initial agreement will be expanded to include structures other than powerplants after the current program of testing is completed in 1990.

The U.S. Nuclear Regulatory Commission has also begun cooperative field testing of a full-scale nuclear powerplant in the Federal Republic of Germany. In a cooperative agreement with the German ministry of power and a private German testing firm, NRC is using a decommissioned nuclear reactor in Karlsruhe as a testbed for vibration testing. To date a large eccentric shaker has been mounted in the plant in order to determine natural frequencies of vibration of the plant and its components. Higher-level shaking tests of piping and other components are scheduled to begin in the coming year, and additional tests are planned through 1990.

In a third program of cooperative testing, NRC, the Electrical Power Research Institute and the Taiwan Power Company have begun to study soil-structure interaction. In these tests, a large simulated powerplant foundation and structure have been constructed in a seismically active region in Taiwan. Various 
forced vibration tests have been conducted on this testbed. Instruments have been placed to measure free-field vibrations from natural earthquakes and to measure the response of the foundation and structure during these earthquakes. This is perhaps the most comprehensive program of testing ever conducted to study soil-structure interaction in connection with a structure of this type on natural soil. To date the site has been shaken by four large earthquakes and valuable data have been gathered. This program promises to be very valuable and relatively inexpensive for all involved. Because the use of the site is dependent in some aspects on naturally occurring earthquakes to provide seismic input, it is impossible to schedule all tests precisely or to know in advance of any shaking how severe the shaking will be. This program of research is expected to continue for several years. 
TABLE C1

\section{RECENT ADDITIONS TO AND UPDATES OF JAPANESE FACILITIES}

\begin{tabular}{|c|c|c|c|}
\hline \multirow{2}{*}{ INSTITUTION } & \multicolumn{3}{|c|}{ FACILITY INSTALLED } \\
\hline & $\begin{array}{cl}\text { TEST BED AND } \\
\text { REACTION }\end{array}$ & $\begin{array}{c}\text { UNIVERSAL } \\
\text { TEST MACHINE }\end{array}$ & $\begin{array}{l}\text { SHAKING } \\
\text { TABLE }\end{array}$ \\
\hline $\begin{array}{l}\text { Public Works Research Institute } \\
\text { Ministry of Construction } \\
\text { (PWRI) }\end{array}$ & $\mathrm{X}$ & $X$ & $\mathrm{X}$ \\
\hline $\begin{array}{l}\text { Shimizu Construction Co. Ltd. } \\
\text { Research Laboratory } \\
\text { (SHIMIZU) }\end{array}$ & & & $\mathrm{X}$ \\
\hline $\begin{array}{l}\text { Ohbayashi-Gumi, Ltd. } \\
\text { Technical Research Institute } \\
\text { (OHBAYASHI) }\end{array}$ & & & $\mathrm{x}$ \\
\hline $\begin{array}{l}\text { Nippon Telegraph and Telephone } \\
\text { Corporation, Tsukuba Engineering } \\
\text { Development Center } \\
\text { (NTT-TEDC) }\end{array}$ & $\mathrm{X}$ & $\mathrm{x}$ & \\
\hline $\begin{array}{l}\text { Okumura Corporation } \\
\text { Tsukuba Research Institute } \\
\text { (OKUMURA) }\end{array}$ & $\mathrm{X}$ & $\mathrm{x}$ & $\mathrm{X}$ \\
\hline $\begin{array}{l}\text { Toda Institute of } \\
\text { Construction Technology } \\
\text { (TODA) }\end{array}$ & $\mathrm{X}$ & $\mathrm{x}$ & \\
\hline $\begin{array}{l}\text { Japanese National Railroad } \\
\text { Technical Research Institute } \\
\text { (JNR) }\end{array}$ & & & $\mathrm{X}$ \\
\hline $\begin{array}{l}\text { Central Research Institute of } \\
\text { Electric Power Industry, Civil } \\
\text { Engineering Lab. (CRIEPI) }\end{array}$ & & & $\mathrm{X}$ \\
\hline $\begin{array}{l}\text { Institute of Industrial Science } \\
\text { University of Tokyo (IIS) }\end{array}$ & $\mathrm{x}$ & $\mathrm{X}$ & $\mathrm{x}$ \\
\hline
\end{tabular}




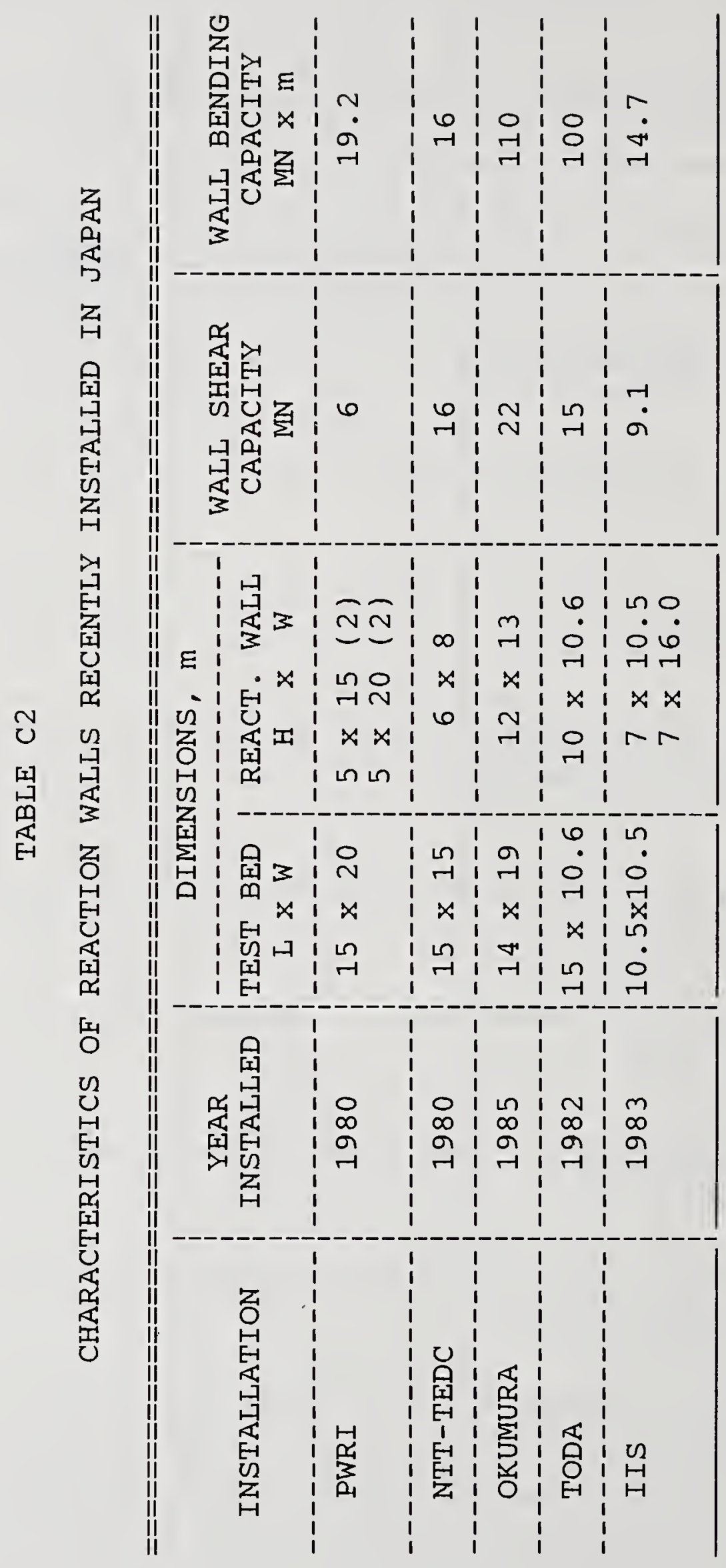




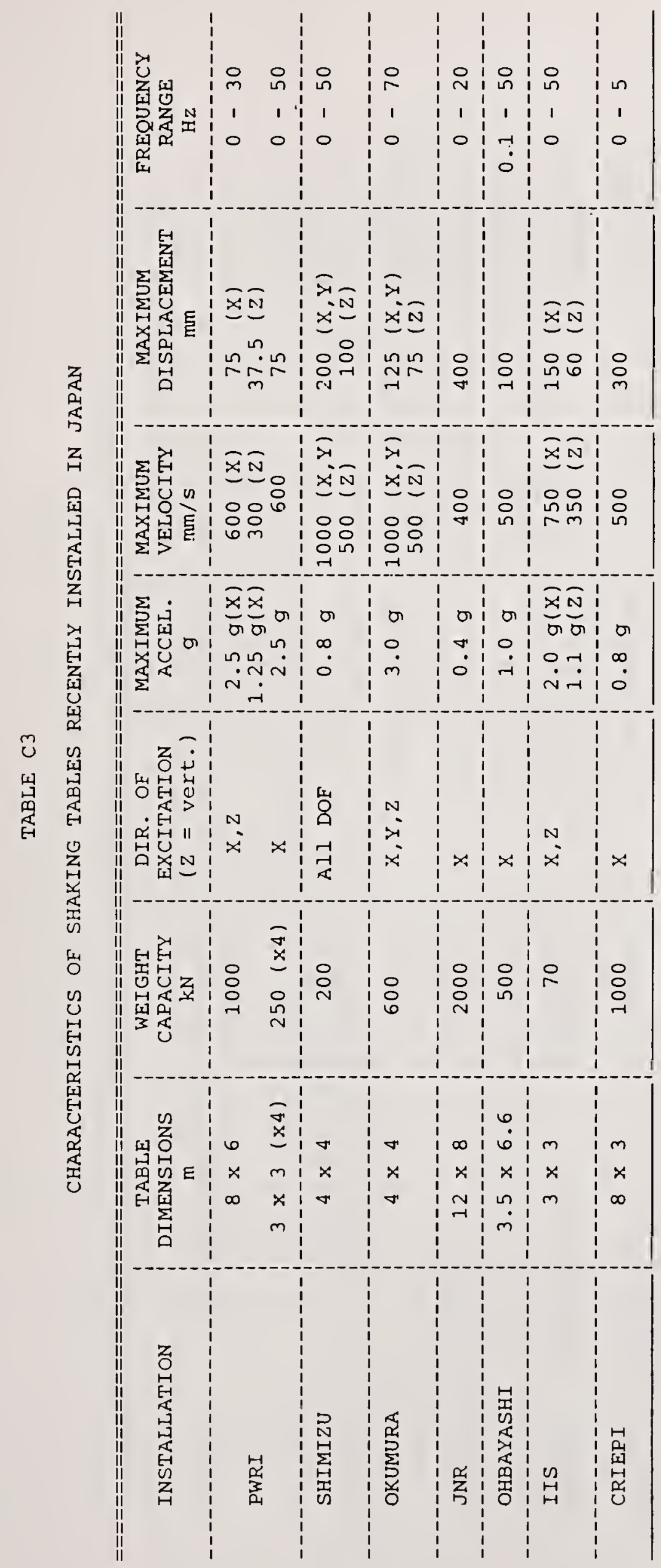




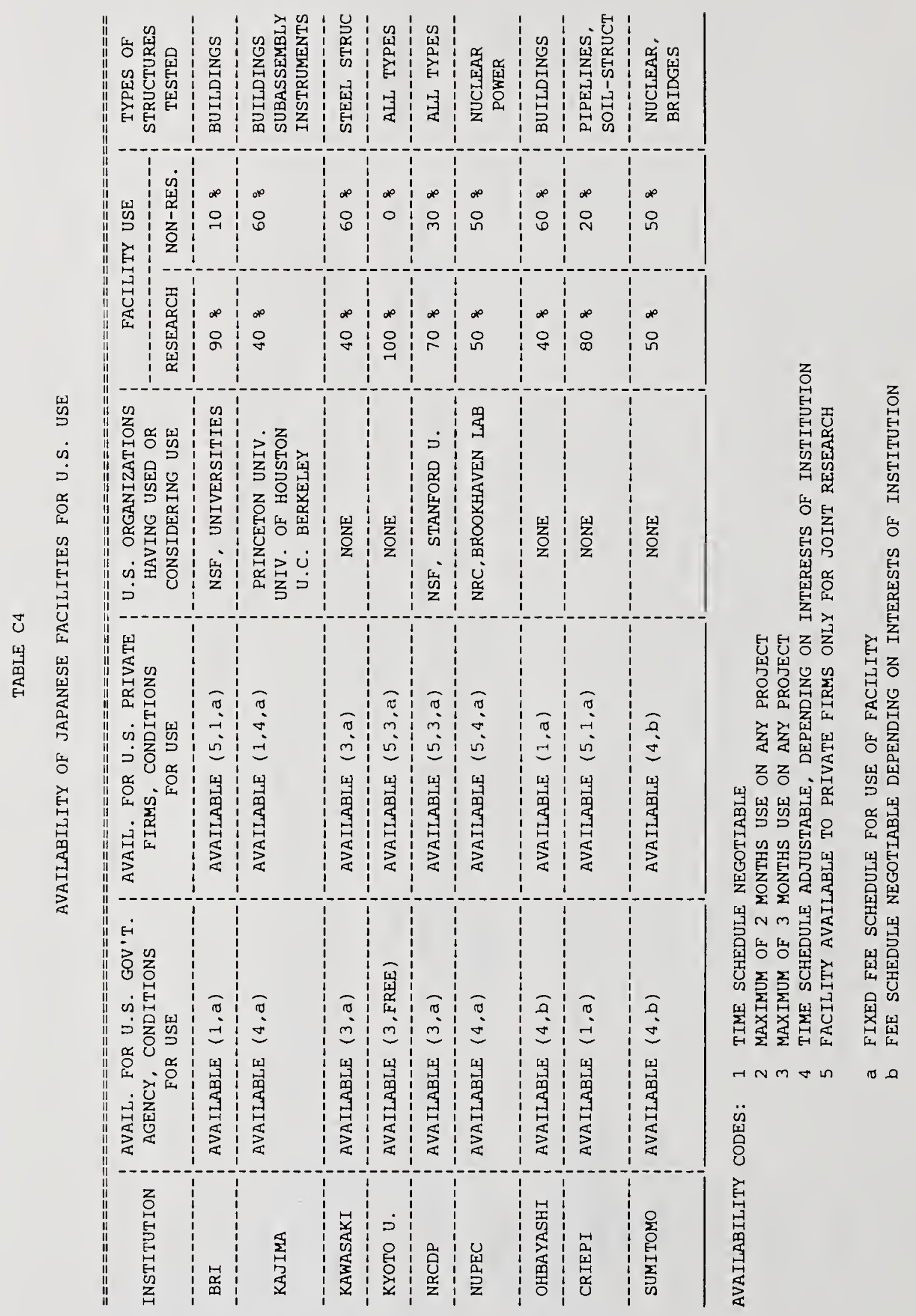




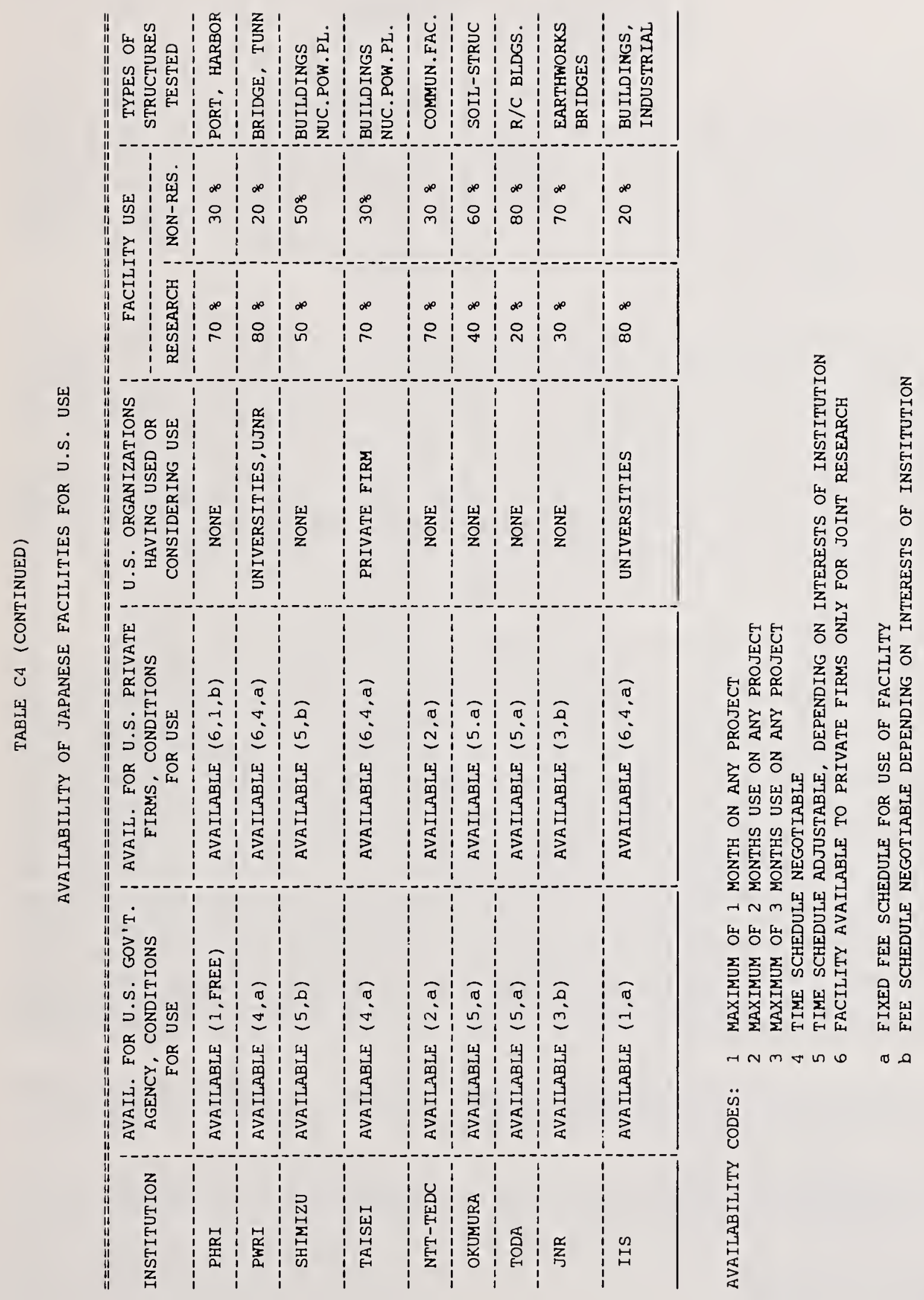




\title{
APPENDIX D
}

\author{
N.E.E.E.F. WORKSHOP \\ GAITHERSBURG, MARYLAND \\ NOVEMBER 18-19，1986
}

An important objective of the first phase of the study was to obtain input from as wide a segment of professional and trade organizations and government agencies as possible. In order to accomplish this objective, a workshop was held in Gaithersburg, Maryland on November 18-19, 1986 to allow all interested groups to hear the recommendations of the six consultants and to offer additional suggestions for needed research.

The six consultants who had been hired to study experimental needs in the six specific areas of interest (low-rise, mediumrise, and high-rise structures, industrial process facilities, power facilities, and lifelines) prepared technical reports (Ref. 5-10) discussing experimental needs and presented their recommendations on the morning of the first day of the workshop. Participants in the workshop were then divided into six working groups to discuss, modify, and add to these recommendations. At the conclusion of the workshop, each of the six working groups reported the results of their discussions.

In arriving at the testing needs identified in Table 1 in the body of this report, a large number of tests were considered in each category. In general, each consultant attempted to identify all tests which might be desirable in the assigned category. As an example, the consultant responsible for determining the testing needs for medium-rise buildings developed a total of twenty-four specific tests needed which ranged from consideration of torsional response of irregular buildings to quantifying the benefits of redundancy in a structure during seismic action. The seven tests recommended finally for mediumrise buildings in Appendix $\mathrm{E}$ were those determined by the consultant and the working group at the workshop to be those most important among all tests considered. A similar procedure was used to identify the most important testing needs for the other categories of structures.

The following individuals participated in the workshop and represented the organizations shown:

Dr. Ahmed M. Abdel-Ghaffar

Dynamics Committee of the Engineering Mechanics Division American Society of Civil Engineers

Dr. Daniel P. Abrams

The Masonry Society 
Dr. Satish Abrol

Headquarters, USAF

Dr. James Beavers

National Research Council

Dr. John J. Burns

U.S. Nuclear Regulatory Commission

Dr. Manmohan S. Chawla

General Services Administration

Dr. Riley M. Chung

National Research Council

Mr. John Coil

Structural Engineers Association of California

Mr. James Cooper

Defense Nuclear Agency

Dr. Charles G. Culver

National Bureau of Standards

Mr. Henry J. Degenkolb

H. J. Degenkolb \& Associates

Dr. A. J. Eggenberger

National Science Foundation

Dr. Mahjoub Elnimeiri

Skidmore, Owings \& Merrill

Mr. William Y. Epling

American Institute of steel construction, Inc.

Mr. Sigmund A. Freeman

Wiss, Janney, Elstner Associates, Inc.

Mr. G. Robert Fuller

Department of Housing and Urban Development

Mr. James Gates

California Department of Transportation

Mr. Peter E. Gurvin

Department of state/FBO

Dr. Robert D. Hanson

National Research Council 
Dr. Walter W. Hays

United States Geological Survey

Mr. James R. Hill

Department of Energy

Mr. Peter Hoffman

McGraw-Hill, Inc.

Dr. George Housner

National Research Council

Dr. Roy A. Imbsen

Imbsen \& Associates, Inc.

Dr. Richard A. Larder

URS Corp./ J.A. Blume \& Associates

Mr. Lon Lister

Federal Energy Regulatory Commission

Dr. Stephen A. Mahin

Committee on Seismic Effects

American Society of Civil Engineers

Dr. William F. Marcuson III

National Research Council

Mr. Harry $W$. Martin

American Iron and Steel Institute

Dr. Francis G. McLean

Bureau of Reclamation

Mr. R. E. Mills, Sr.

Steel Plate Fabricators Association

Ms. Janina V. Mirski

Veterans Administration

Dr. Joseph Reynen

Commission of the European Communities

Dr. Henry G. Russell

Portland Cement Association

Dr. Michael Sbaglia

American Insurance Services, Inc.

Dr. Charies F. Scheffey

Federal Highway Administration 
Dr. Charles F. Scribner

National Bureau of Standards

Mr. Robert spangler

Council of American Building officials

Dr. John A. Stevenson

Stevenson \& Associates

Mr. Joseph Tyrrell

Naval Facilities Engineer Command

Mr. Charles W. C. Yancey

National Bureau of Standards

Dr. Arthur J. Zeizel

Federal Emergency Management Agency 
The following organizations were also given the opportunity to review the recommendations developed at the workshop and to offer further needs for experimentation:

American Assoc. of State Highway and Trans. Officials American Concrete Institute

American Consulting Engineers Council

American Institute of Timber Construction

American Plywood Association

American Society of Heating, Refrigerating, and Air Conditioning Engineers, Inc.

American Society of Mechanical Engineers

American Society for Testing and Materials

Applied Technology Council

Associated General Contractors of America

Association of Major City Building officials

Brick Institute of America

Building officials and Code Administrators, International

Building Seismic Safety Council

Concrete Masonry Association of California and Nevada

Concrete Reinforcing Steel Institute

Council on Tall Buildings

Earthquake Engineering Research Institute

Electric Power Research Institute

International Conference of Building officials

Metal Building Manufacturers Association

National Association of Home Builders

National Concrete Masonry Association

National Conference of States on Building codes and Standards

National Electrical Manufacturers Association

National Forest Products Association

National Ready-Mixed Concrete Association

Nuclear Regulatory Commission

Post-Tensioning Institute

Prestressed Concrete Institute

Rack Manufacturers Institute

Southern Building Code Congress International

Steel Deck Institute, Inc.

Structural Engineers Association of Arizona

Structural Engineers Association of Utah

United States Forest Products Laboratory

University Council on Earthquake Engineering Research

Western States Council structural Engineers Association

Western States Clay Products Association 


\section{APPENDIX E \\ RECOMMENDATIONS FOR LARGE-SCALE TESTING}

For the purposes of this report, needs for large-scale seismic testing were considered for low-rise, medium-rise, and high-rise buildings, industrial processing facilities, power facilities, and lifelines. Recommendations were developed for all areas except lifelines. The recommendations for research in the area of lifelines were concerned primarily with bridges. These research needs and recommendations for the facilities required to conduct this research have not been presented here for two reasons. First, these recommendations were similar in nature to those presented previously in a report on research needs for bridges (see Appendix A, Workshop 3). Second, many of the tests recommended can be done more appropriately as in-situ tests on actual structures rather than in a central laboratory. These tests, although important to a total program of seismic testing, are not of interest to this study of a national facility.

The following sections summarize the needs for research and recommendations for testing identified as being appropriate to a national experimental facility. The recommended tests in each section are listed in priority order.

\section{A. LOW-RISE STRUCTURES}

For the purposes of this report, low-rise buildings were defined as those structures less than four stories high. Such buildings can be tested under static lateral loads using a large reaction wall. In addition, many low-rise structures, such as wood-frame residential buildings, are small enough to fit on a large shaking table. Low-rise structures often consist of an assemblage of several similar or identical modules, one of which also might be small enough to fit on a large shaking table.

\section{RECOMMENDATION Al: TILT-UP CONSTRUCTION}

TESTS ARE NEEDED TO DETERMINE THE BEHAVIOR OF TILT-UP CONSTRUCTION HAVING PANALIZED PLYWOOD ROOF DIAPHRAGMS

A full scale test of a single-story tilt-up industrial building is needed to study the behavior and response of this type of structure, particularly of a panalized plywood roof diaphragm, the interaction of walls and roofs, and the response of connections between the roof and walls. 
Facility requirements for this test:

Shaking Table:

Size: $9 \mathrm{~m} \times 18 \mathrm{~m}$

Weight Capacity: $1330 \mathrm{kN}$

Maximum Acceleration: $0.6 \mathrm{~g} ., \mathrm{X}, \mathrm{Y}$ directions

Frequency Range: $0.2-20 \mathrm{~Hz}$.

Estimated level of effort for this project: 4 man-years

Note: Additional review of this type of structure has indicated that there may be some difficulties in developing a test model that will accurately simulate actual conditions. In lieu of a shaking table test, individual actuators may have to be used. Additional study will be required to develop more accurately the test facility requirements.

RECOMMENDATION A2: WOOD-FRAME RESIDENTIAL HOUSING

TESTS ARE NEEDED TO DETERMINE THE PERFORMANCE OF A TWOSTORY WOOD-FRAME RESIDENTIAL BUILDING

Tests of a two-story wood-frame residential structure would be designed to determine overall response of this class of structure, deformation patterns of walls and roofs, interaction between components of the structure, and behavior of connections, non-structural partitions, and foundation anchorages.

Facility Requirements for This Test:

Shaking Table:

Size: $8 \mathrm{~m} \times 12 \mathrm{~m}$

Weight Capacity: $180 \mathrm{kN}$

Maximum Acceleration: $0.6 \mathrm{~g} ., \mathrm{X}, \mathrm{Y}$ directions

Frequency Range: $0.2-20 \mathrm{~Hz}$.

Estimated level of effort for this project: 3 man-years

RECOMMENDATION A3: SPLIT-LEVEL RESIDENTIAL STRUCTURE

TESTS ARE NEEDED TO DETERMINE THE PERFORMANCE OF SPLITLEVEL RESIDENTIAL STRUCTURES

The test of a two-story split-level residential structure having a large garage door opening would provide information about the interaction between sections of the structure and the effects of the garage door opening on the performance of the structure. This configuration of test specimen would also be used to investigate the methods of tying together sections of residential structures. 
Facility Requirements for This Test:

Shaking Table:

Size: $12 \mathrm{~m} \times 12 \mathrm{~m}$

Weight Capacity: $270 \mathrm{kN}$

Maximum Acceleration: $0.6 \mathrm{~g} ., \mathrm{X}, \mathrm{Y}$ directions

Frequency Range: $0.2-20 \mathrm{~Hz}$.

Estimated level of effort for this project: 3 man-years

RECOMMENDATION A4: CAVITY-WALL MASONRY STRUCTURE

DYNAMIC TESTS OF MASONRY STRUCTURES SUBJECT TO MODERATE EARTHQUAKES ARE NEEDED

A large number of commercial structures in the eastern U.S. and in other regions of the country in which seismic risk is low are of cavity wall masonry construction, in which two wythes of masonry units are separated by an air space and held together with metal ties. The test of such a structure under moderate seismic forces (maximum lateral accelerations of $0.2 \mathrm{~g}$.) would help to determine its resistance to lateral loads and would serve as a proof test of this common type of construction.

Facility Requirements for This Test:

Shaking Table:

Size: $8 \mathrm{~m} \times 12 \mathrm{~m}$

Weight Capacity: $800 \mathrm{kN}$

Maximum Acceleration: $0.6 \mathrm{~g} ., \mathrm{X}, \mathrm{Y}$ directions

Frequency Range: $0.2-20 \mathrm{~Hz}$.

Estimated level of effort for this project: 6 man-years

RECOMMENDATION A5: LIGHT-WEIGHT STEEL STRUCTURES

DYNAMIC TESTS OF A THREE-STORY OFFICE BUILDING ARE NEEDED TO DETERMINE THE SEISMIC RESISTANCE OF LIGHT-WEIGHT METAL MOMENT FRAMES

A common form of construction for small office buildings consists of lightweight steel moment frames formed by tubular columns and open web joists. Tests of a three-bay by three-bay structure of this type are needed to determine the performance of this popular type of construction during earthquakes. Although a typical prototype structure would be approximately $30 \mathrm{~m}$ square in plan, it is believed that a $2 / 3$ scale model would accurately demonstrate the performance of the structure. 
Facility Requirements for This Test:

Shaking Table:

Size: $18 \mathrm{~m} \times 18 \mathrm{~m}$

Weight Capacity: $3600 \mathrm{kN}$

Maximum Acceleration: $0.6 \mathrm{~g} ., \mathrm{X}, \mathrm{Y}$ directions

Frequency Range: $0.2-20 \mathrm{~Hz}$.

Estimated level of effort for this project: 5 man-years

RECOMMENDATION A6: MOBILE HOME ANCHORAGE

DYNAMIC TESTS ARE NEEDED TO CERTIFY SYSTEMS FOR ANCHORING MOBILE HOMES

Mobile homes are manufactured in sizes as large as $4.3 \mathrm{~m}$ by $22 \mathrm{~m}$ for single-width homes and 8.6 by $15 \mathrm{~m}$ for double-width homes. One of the critical aspects of the performance of these manufactured homes is the system used to anchor the structure to either the soil or to a prepared foundation. A shaking table could be used to test and certify the various systems designed to anchor these homes against both wind and earthquake loads.

Facility Requirements for This Test:

Shaking Table:

Size: $9 \mathrm{~m} \times 18 \mathrm{~m}$

Weight Capacity: $180 \mathrm{kN}$

Maximum Acceleration: $0.6 \mathrm{~g} ., \mathrm{X}, \mathrm{Y}$ directions

Frequency Range: $0.2-20 \mathrm{~Hz}$.

Estimated level of effort for this project: 2 man-years

\section{B. MEDIUM-RISE STRUCTURES}

For purposes of this report, medium-rise structures were considered to be those between four and fifteen stories in height. Medium-rise structures make up a majority of commercial construction. Full-scale medium-rise concrete and steel frame structures have been tested using a very large reaction wall in Tsukuba, Japan, and a full-scale medium-rise masonry structure is currently being prepared for testing. The following research needs and tests necessary to satisfy those needs have been identified:

RECOMMENDATION B1: CONCRETE FRAME STRUCTURES

TESTS OF FULL-SCALE MOMENT FRAME AND DUCTILE MOMENT FRAME STRUCTURES ARE NEEDED TO DETERMINE THE BEHAVIOR OF THESE STRUCTURAL SYSTEMS UNDER LATERAL LOADING

Full-scale static lateral load tests of a medium-rise concrete frame structure have been conducted in Japan. However, the details of reinforcement used in that structure were not the same as those used in similar structures in the U.S. Tests of concrete frame structures containing reinforcement detailed in 
accordance with U.S. practice are needed. A test of a ductile moment frame structure would address the needs of designers of structures built in zones of severe seismic risk. The test of an ordinary moment frame structure would examine the behavior of concrete frame structures built in regions of low seismic risk.

Facility Requirements for This Test:

Shaking Table:

Size: $9 \mathrm{~m} \times 9 \mathrm{~m}$

Weight Capacity: $12,900 \mathrm{kN}$

Maximum Acceleration: $0.8 \mathrm{~g} ., \mathrm{X}, \mathrm{Y}$ directions

Frequency Range: $0-30 \mathrm{~Hz}$.

Reaction Wall:

Test Bed Dimensions: $18 \mathrm{~m} \times 18 \mathrm{~m}$

Reaction Wall Height: $23 \mathrm{~m}$

Wall Shear Capacity: $5.60 \mathrm{MN}$

Wall Moment Capacity: $82 \mathrm{MN}-\mathrm{m}$

Estimated level of effort for this project: 6 man-years

RECOMMENDATION B2: STEEL MOMENT FRAME STRUCTURE

TESTS OF A STEEL MOMENT FRAME STRUCTURE CARRYING FULL DEAD LOAD AND LATERAL LOADS APPLIED IN ORTHOGONAL DIRECTIONS ARE NEEDED

A full-scale steel braced frame structure has been tested in Japan. This test did not address the behavior of steel moment frame structures, which make up a large percentage of steel frame structures in seismic regions of the U.S. A test of a 7-story steel moment frame structure carrying full dead load and lateral load applied in orthogonal directions is needed to define the behavior of this important type of structure. 
Facility Requirements for This Test:

Shaking Table:

Size: $9 \mathrm{~m} \times 9 \mathrm{~m}$

Weight Capacity: $10,000 \mathrm{kN}$

Maximum Acceleration: $0.8 \mathrm{~g} ., \mathrm{X}, \mathrm{Y}$ directions

Frequency Range: $0-30 \mathrm{~Hz}$.

Reaction Wall:

Test Bed Size: $18 \mathrm{~m} \times 18 \mathrm{~m}$

Reaction Wall Height: $27 \mathrm{~m}$

Wall Shear Capacity: $5.60 \mathrm{MN}$

Wall Moment Capacity: $82 \mathrm{MN}-\mathrm{m}$

Estimated level of effort for this project: 6 man-years

RECOMMENDATION B3: MEDIUM-RISE STRUCTURES WITH BASE ISOLATION

TESTS OF A MEDIUM RISE STRUCTURE INCORPORATING A SYSTEM OF BASE ISOLATION DEVICES IS NEEDED

The use of base isolation devices to reduce earthquake damage is receiving considerable attention. Controlled tests of full-scale structures incorporating such devices are needed to provide performance data on their functioning and effect on structural response.

Facility Requirements for This Test:

Same as for Recommendation B1.

Estimated level of effort for this project: 3 man-years RECOMMENDATION B4: DYNAMIC TEST OF BUILDING WITH SOFT STORY

TESTS OF A STEEL FRAME STRUCTURE HAVING A SOFT STORY ARE NEEDED

As a result of commercial use, the first story of many medium-rise structures is quite flexible (soft story). Test data are needed for such structures. This test can be conducted in conjunction with the test of the steel moment frame structure recommended above.

Facility Requirements for This Test:

Same as for Recommendation B2.

Estimated level of effort for this project: 3 man-years (to be done in conjunction with other projects) 
RECOMMENDATION B5: FULL-SCALE TESTS OF NON-STRUCTURAL COMPONENTS

TESTS ARE NEEDED TO DETERMINE THE BEHAVIOR OF NONSTRUCTURAL COMPONENTS COMMON IN STEEL MOMENT FRAME STRUCTURES

Non-structural components of structures subjected to earthquakes present a serious problem for designers and represent one of the greatest expenses associated with damage from earthquakes, even if the structure remains relatively intact. Tests are needed to determine the contribution of various types of curtain walls and other non-structural components to the stiffness and strength of frame structures and to determine the behavior of anchorage systems used to connect non-structural and structural elements. These tests could be most efficiently done in connection with the test of the steel frame structure recommended above.

Facility Requirements for This Test:

Same as for Recommendation B2.

Estimated level of effort for this project: 2 man-years

RECOMMENDATION B6: PRECAST COMPONENTS

TESTS ARE NEEDED TO DETERMINE THE BEHAVIOR OF STRUCTURES CONSTRUCTED FROM PRECAST COMPONENTS

It is recommended that a seven-story reinforced masonry bearing wall structure having precast components be tested. This structure should contain precast floors, both with and without topping, in addition to other selected precast components.

Facility Requirements for This Test:

Shaking Table:

Size: $9 \mathrm{~m} \times 9 \mathrm{~m}$

Weight Capacity: $7,100 \mathrm{kN}$

Maximum Acceleration: $0.8 \mathrm{~g} ., \mathrm{X}, \mathrm{Y}$ directions

Frequency Range: $0-30 \mathrm{~Hz}$.

Reaction Wall:

Test Bed Size: $18 \mathrm{~m} \times 18 \mathrm{~m}$

Reaction Wall Height: $23 \mathrm{~m}$

Wall Shear Capacity: $8.9 \mathrm{MN}$

Wall Moment Capacity: $136 \mathrm{MN}-\mathrm{m}$

Estimated level of effort for this project: 6 man-years 
RECOMMENDATION B7: STEEL STUDS AND GYPSUM BOARD SHEATHING

TESTS ARE NEEDED TO DETERMINE THE BEHAVIOR OF WALLS CONSTRUCTED OF LIGHT-GAGE STEEL STUDS AND GYPSUM BOARD SHEATHING

A five- or six-story structure would be used as a vehicle to examine the behavior of walls constructed of light-gage steel studs and gypsum boards. Walls of this type are common in light office construction, but their contribution to the stiffness and strength of the structure is unknown.

Facility Requirements for This Test:

Same as for Recommendation B2.

Estimated level of effort for this project: 4 man-years

\section{HIGH-RISE STRUCTURES}

High-rise structures, defined here as those structures taller than fifteen stories, present a unique set of problems, not only for designers, but for those contemplating full-scale or large-scale tests of representative structures. Even the largest feasible shaking tables or reaction walls are not large enough to test a complete high-rise structure at a large scale. In addition, a test of a large-scale three-dimensional model of a high-rise structure could be prohibitively expensive.

It will probably never be possible to test a complete, fullscale, high-rise structure in any laboratory. The types of tests recommended for determining behavior of high-rise structures may be divided into either quarter-scale tests of complete structures or full-scale tests of structural components. The specific research recommendations which have been identified include the following:

RECOMMENDATION CI: FRAMED TUBE SUBASSEMBLY

FULL-SCALE TESTS OF COMPONENTS OF A FRAMED TUBE ARE NEEDED TO DEFINE BEHAVIOR OF THAT TYPE OF STRUCTURE

A full-scale test of a subassembly of a framed tube structure is needed to study behavior of such a system having strong beams and relatively weaker columns. This test would determine the effects of localized yielding on redistribution of forces within the system, the ability of the system to maintain its load-carrying capacity, and P-delta effects. Quarter-scale tests are proposed. 
Facility Requirements for This Test:

Shaking Table:

Size: $9 \mathrm{~m} \times 9 \mathrm{~m}$

Weight Capacity: $4,450 \mathrm{kN}$

Maximum Acceleration: $0.6 \mathrm{~g} ., \mathrm{X}, \mathrm{Y}$ directions

Frequency Range: $0-15 \mathrm{~Hz}$.

Estimated level of effort for this project: 4 man-years

RECOMMENDATION C2: ENERGY-DISSIPATING DEVICES

TESTING OF ENERGY DISSIPATING DEVICES ARE NEEDED TO DETERMINE THE EFFECTS OF THOSE DEVICES ON STRUCTURAL RESPONSE

Energy dissipating devices can be installed throughout a high-rise structure, but their effect on performance has never been experimentally verified. The ability to conduct full-scale tests would stimulate development of the components and confidence in their performance.

Facility Requirements for This Test:

Same as for Recommendation $\mathrm{Cl}$.

Estimated level of effort for this project: 2 man-years

RECOMMENDATION C3: DUAL SYSTEMS

TESTS ARE NEEDED TO VERIFY THE DISTRIBUTION OF LOADS BETWEEN COMPONENTS OF DUAL STRUCTURAL SYSTEMS

Full- or large-scale tests of subassemblies of structures having dual systems designed to carry lateral loads. Tests are needed to determine the manner in which lateral loads are carried by the components of the system up to failure.

Facility Requirements for This Test:

Shaking Table:

Size: $9 \mathrm{~m} \times 9 \mathrm{~m}$

Weight Capacity: $4,450 \mathrm{kN}$

Maximum Acceleration: $0.6 \mathrm{~g} ., \mathrm{X}, \mathrm{Y}$ directions

Frequency Range: $0-15 \mathrm{~Hz}$.

Estimated level of effort for this project: 6 man-years 


\section{INDUSTRIAL PROCESSING FACILITIES}

Industrial processing facilities include a wide variety of structures, equipment, and mechanical components such as large tanks, pressure vessels, piping, furnaces, and stacks. Many existing facilities were designed without consideration of earthquake loading and at a time when little was known about the characteristics of earthquake loads or the appropriate means of resisting these loads. The following summarize the recommendations for tests requiring a large national facility:

RECOMMENDATION D1: UNANCHORED TANKS

DYNAMIC TESTS OF UNANCHORED LIQUID-FILLED TANKS ARE NEEDED

Shaking table tests of unanchored tanks are needed to determine behavior of liquid filled tanks having floating roofs, open roofs, or closed roofs. These tests would be designed to study the effects of motions of the liquid within the tanks on buckling and failure of the tank walls and to study the behavior of piping connections to the tank.

Facility Requirements for This Test:

Shaking Table:

Size: $15 \mathrm{~m} \times 15 \mathrm{~m}$

Weight Capacity: $14,200 \mathrm{kN}$

Maximum Acceleration: $1.0 \mathrm{~g} . \mathrm{X}, 1.0 \mathrm{~g} . \mathrm{Y}, 0.5 \mathrm{~g} . \mathrm{Z}$

Maximum Displacements: $250 \mathrm{~mm}$ horizontal, $25 \mathrm{~mm}$ vertical Maximum Velocity: $760 \mathrm{~mm} / \mathrm{sec}$.

Frequency Range: $0-10 \mathrm{~Hz}$.

Estimated level of effort for this project: 6 man-years

\section{RECOMMENDATION D2: RETROFIT MEASURES}

TESTS OF RETROFIT METHODS FOR EXISTING INDUSTRIAL PLANTS ARE NEEDED TO DETERMINE PERFORMANCE OF THOSE METHODS OF STRENGTHENING

The vast majority of existing industrial plants were constructed either without consideration of or with crude consideration of seismic response of the plants. Full-scale tests would be designed not only to determine the behavior of existing plants, but also the effectiveness of proposed methods of retrofit. 
Facility Requirements for This Test:

Shaking Table:

Size: $20 \mathrm{~m} \times 20 \mathrm{~m}$

Weight Capacity: $16,000 \mathrm{kN}$

Maximum Acceleration: $0.5 \mathrm{~g} ., \mathrm{X}, \mathrm{Y}, \mathrm{Z}$ directions

Maximum Displacement: $250 \mathrm{~mm}$

Maximum Velocity: $760 \mathrm{~mm} / \mathrm{sec}$

Frequency Range: $0.1-30 \mathrm{~Hz}$.

Reaction Wall:

$18 \mathrm{~m} \times 3 \mathrm{~m}$ test bed

L-shaped Reaction Wall Height: $12 \mathrm{~m}$

Wall Shear Capacity: 2.2 MN

Wall Moment Capacity: $20.3 \mathrm{MN}-\mathrm{m}$

Estimated level of effort for this project: 6 man-years

RECOMMENDATION D3: CHEMICAL AND REFINERY EQUIPMENT

TESTS OF REFINERY AND CHEMICAL PLANT COMPONENTS ARE NEEDED TO DETERMINE BEHAVIOR OF SELECTED COMPONENTS

Tests of several types of large components of chemical plants and refineries are needed. These components include the following:

Spherical and cylindrical pressure vessels Piping systems

Cracking towers with piping

stacks and chimneys

Facility requirements for these tests would be the same as those for unanchored tanks discussed above. An added condition of the test facility would be that $100 \mathrm{ft}$ overhead clearance would be required for the shaking table to accommodate the stacks and cracking towers at an acceptable scale.

Estimated level of effort for this project: 7 man-years

\section{E. POWER FACILITIES}

Because of the many critical large electrical and mechanical components present in a typical power-generating or power transmission facility, the tests which are most needed by this industry are those which could determine the behavior of these major structural and mechanical components. The recommendations for testing are the following: 


\section{RECOMMENDATION EI: PLANT COMPONENTS}

TESTS ARE NEEDED TO DETERMINE THE RESPONSE OF CRITICAL COMPONENTS OF POWER-GENERATING FACILITIES TO SEISMIC LOADING

A large number of the mechanical components of powergenerating facilities are unique to those facilities. Tests of either full-scale components or of models are needed for two reasons. First, scale model tests of some components on a shaking table could increase understanding of the behavior of these components and help their designers to make them more efficient and safer from a structural standpoint. Second, fullscale tests of some critical components are needed as proof tests. The components to be tested, either at full scale or at reduced scale could include diesel generators, gas turbines, suspended boilers, coal handling systems, large-diameter high temperature ducts, and large suspended ceilings typical of those used in control rooms.

Facility Requirements for These Tests:

Shaking Table:

Size: $9 \mathrm{~m} \times 9 \mathrm{~m}$

Weight Capacity: $4,450 \mathrm{kN}$

Maximum Acceleration: $0.5 \mathrm{~g} ., \mathrm{X}, \mathrm{Y}, \mathrm{Z}$ directions

Maximum Displacement: $250 \mathrm{~mm}$

Maximum Velocity: $760 \mathrm{~mm} / \mathrm{sec}$

Frequency Range: $0.1-30 \mathrm{~Hz}$.

Estimated level of effort for this project: 5 man-years

\section{RECOMMENDATION E2: DISTRIBUTION SYSTEMS}

FULL-SCALE TESTS OF COMPONENTS OF ELECTRICAL DISTRIBUTION SYSTEMS ARE NEEDED AS QUALIFICATION TESTS

Several failures of equipment at electrical distribution substations have highlighted the need for qualification tests of full-scale production components. The components should include large transformers, large switchgear, and other critical elements of power distribution systems.

Facility Requirements for This Test:

Shaking Table:

Size: $9 \mathrm{~m} \times 9 \mathrm{~m}$

Weight Capacity: $4,450 \mathrm{kN}$

Maximum Acceleration: $0.5 \mathrm{~g} ., \mathrm{X}, \mathrm{Y}, \mathrm{Z}$ directions

Maximum Displacement: $250 \mathrm{~mm}$

Maximum Velocity: $760 \mathrm{~mm} / \mathrm{sec}$

Frequency Range: $0.1-30 \mathrm{~Hz}$.

Estimated level of effort for this project: 4 man-years 
LARGE-SCALE TESTS ARE NEEDED TO DETERMINE EFFECTS OF SOILSTRUCTURE INTERACTION ON SEISMIC RESPONSE OF STRUCTURES

The inability to successfully scale soil particle sizes leads to a need to perform large-scale tests of effects of soilstructure interaction on seismic response of powerplant structures. A large shaking table would be required to conduct coupled soil-structure tests with controlled input motions and realistic dimensions and boundary conditions. Such tests could include consideration of rigid concrete structures on raft or pile foundations, flexible steel structures on spread footings or piles, and the response of buried tanks, tunnels, shafts, and piping.

Facility Requirements for This Test:

Shaking Table:

Size: $15 \mathrm{~m} \times 15 \mathrm{~m}$

Weight Capacity: $13,300 \mathrm{kN}$

Maximum Acceleration: $0.5 \mathrm{~g} ., \mathrm{X}, \mathrm{Y}, \mathrm{Z}$ directions

Maximum Displacement: $250 \mathrm{~mm}$

Maximum Velocity: $760 \mathrm{~mm} / \mathrm{sec}$

Frequency Range: $0.1-30 \mathrm{~Hz}$.

Estimated level of effort for this project: 6 man-years

RECOMMENDATION E4: TRANSMISSION TOWERS

TESTS ARE NEEDED TO DEFINE THE RESPONSE OF TRANSMISSION TOWERS TO SEISMIC LOADING

Because the overturning stability of some configurations of transmission towers is related to the absolute displacement of the ground during seismic loading, a large-scale test of such towers is needed to properly represent their potential to overturn. Tests for both truss-type and pole-type towers are recommended.

Facility Requirements for This Test:

Shaking Table:

Size: $9 \mathrm{~m} \times 9 \mathrm{~m}$

Weight Capacity: $2,200 \mathrm{kN}$

Maximum Acceleration: $0.5 \mathrm{~g}, \mathrm{X}, \mathrm{Y}, \mathrm{Z}$ directions

Maximum Displacement: $250 \mathrm{~mm}$

Maximum Velocity: $760 \mathrm{~mm} / \mathrm{sec}$

Frequency Range: $0.1-30 \mathrm{~Hz}$.

Estimated level of effort for this project: 2 man-years 


\section{APPENDIX F \\ NATIONAL ACADEMY OF SCIENCE \\ ADVISORY PANEL}

\section{CHAIRMAN}

Dr. James E. Beavers

Martin Marietta Energy systems, Inc.

Bldg. 9733-4, MS-2

P. O. BoX Y

Oak Ridge, Tennessee 37831

MEMBERS OF THE PANEL

Dr. Mirhan S. Agbabian

Department of Civil Engineering

University of Southern California

Los Angeles, California 90089-0242

Dr. Robert D. Hanson

Department of Civil Engineering

2340 G. G. Brown Laboratory

University of Michigan

Ann Arbor, Michigan 48109-2125

Dr. George W. Housner

Mail Code 104-44

California Institute of Technology

Pasadena, California 91125

Dr. James O. Jirsa

Finch Professor of Civil Engineering

Ferguson structural Engineering Laboratory

University of Texas

10100 Burnet Road

Austin, Texas 78758

Dr. William F. Marcuson III

USAE Waterways Experiment station

WES-GV-Z

P. O. Box 631

Vicksburg, Mississippi 39180

Dr. Joseph Penzien

Room 731, Davis Hall

University of California

Berkeley, California 94720 


\section{LIAISON REPRESENTATIVES}

Dr. William A. Anderson Program Director, Earthquake systems Integration Division of Emerging and Critical Engineering Systems National Science Foundation

Washington, D. C. 20550

Mr. James Cooper

Strategic structures Branch

Defense Nuclear Agency

Washington, D. C. 20305

Dr. James Costello

Mechanical/Structural Engineering Branch

Division of Engineering Technology

office of Nuclear Regulatory Research

Nuclear Regulatory Commission

Washington, D. C. 20555

Mr. Richard F. Davidson

Civil Engineering, Geotechnical Branch office

Chief of Engineers, U. S. Army

HQDA (DAEN-CWE-SS)

Washington, D. C. 20314

Dr. Walter $W$. Hays

Deputy for Research Applications

office of Earthquakes, Volcanoes \& Engineering

U. S. Geological Survey

National Center, MS 905

Reston, Virginia 22092

Mr. Joseph Tyrrell

Code 045

Naval Facilities Engineering Command

200 Stovall Street

Alexandria, Virginia 22332

Dr. Arthur J. Zeizel

Office of Natural and Technological Hazards Program

State and Local Programs and support

Federal Emergency Management Agency

Washington, D. C. 20472 
NATIONAL RESEARCH COUNCIL STAFF

Dr. Riley M. Chung

Mr. O. A. Israelson

Mrs. Lallyanne Anderson

Ms. Denise A. Grady

Committee on Earthquake Engineering

National Research Council

414 Joseph Henry Building

2101 Constitution Avenue, NW

Washington, D. C. 20418 
NBS.114A (REV. 2-BC)

U.S. DEPT. OF COMM.

1. PUBLICATION OR

REPORT NO
NBS/SP-729

2. Performing Organ. Report No. 3. Publication Date

BIBLIOGRAPHIC DATA

SHEET (See instructions)

Apri 11987

4. TITLE AND SUBTITLE

National Earthquake Engineering Experimental

Facility Study

Phase One - Large Scale Testing Needs

5. $A \cup T H O R(S)$

Charles F. Scribner and Charles G. Culver

6. PERFORMING ORGANIZATION (If joint or other than NBS, see instructions)

NATIONAL BUREAU OF STANDARDS

DEPARTMEN T OF COMMERCE

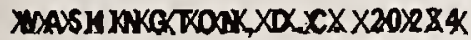

Gaithersburg, MD 20899

9. SPONSORING ORGANIZATION NAME AND COMPLETE ADDRESS (Street, City. State, ZIP)

Federal Emergency Management Agency

National Science Foundation

National Bureau of Standards

10. SUPPLEMENTARY NOTES

Library of Congress Catalog Card Number: 87-619811

Document describes a computer program; SF-185, FIPS Software Summary, is attached.

11. ABSTRACT (A 200-word or less factual summary of most significant information. If document includes a significant bibliography or literature survey. mention it here)

This report summarizes information obtained during the first year of a four-year feasibility study for a national earthquake engineering experimental facility. A five-year research program is presented for a national facility in which full-scale or large-scale structures or structural components would be subjected to static or dynamic lateral loads. The facility would have applicability to tests in the following areas: low-rise buildings, medium-rise buildings, high-rise buildings, industrial processing facilities, and power facilities. Representatives from a broad spectrum of professional, industrial, and trade organizations and Federal agencies participated in developing the research program. A comparison of existing testing facilities in the U.S. and other countries engaged in seismic testing and a discussion of international cooperation in large-scale testing are included.

12. KEY WORDS (Six to twelve entries: alphabetical order: capitalize only proper names; and separate key words by semicolons) buildings; earthquakes; laboratories; research; structural engineering; tests

13. AVAILABILITY

XX] Unlimited

For Official Distribution. Do Not Release to NTIS

XX] Order From Superintendent of Documents, U.S. Government Printing Office, Washington, D.C. 20402.

Order From National Technical Information Service (NTIS), Springfield, VA. 2216I

14. NO. OF

PRINTED PAGES

70

15. Price 



\section{Technical Publications}

\section{Periodical}

Journal of Research-The Journal of Research of the National Bureau of Standards reports NBS research and development in those disciplines of the physical and engineering sciences in which the Bureau is active. These include physics, chemistry, engineering, mathematics, and computer sciences. Papers cover a broad range of subjects, with major emphasis on measurement methodology and the basic technology underlying standardization. Also included from time to time are survey articles on topics closely related to the Bureau's technical and scientific programs. Issued six times a year.

\section{Nonperiodicals}

Monographs-Major contributions to the technical literature on various subjects related to the Bureau's scientific and technical activities.

Handbooks-Recommended codes of engineering and industrial practice (including safety codes) developed in cooperation with interested industries, professional organizations, and regulatory bodies.

Special Publications-Include proceedings of conferences sponsored by NBS, NBS annual reports, and other special publications appropriate to this grouping such as wall charts, pocket cards, and bibliographies.

Applied Mathematics Series-Mathematical tables, manuals, and studies of special interest to physicists, engineers, chemists, biologists, mathematicians, computer programmers, and others engaged in scientific and technical work.

National Standard Reference Data Series-Provides quantitative data on the physical and chemical properties of materials, compiled from the world's literature and critically evaluated. Developed under a worldwide program coordinated by NBS under the authority of the National Standard Data Act (Public Law 90-396).

NOTE: The Journal of Physical and Chemical Reference Data (JPCRD) is published quarterly for NBS by the American Chemical Society (ACS) and the American Institute of Physics (AIP). Subscriptions, reprints, and supplements are available from ACS, 1155 Sixteenth St., NW, Washington, DC 20056.

Building Science Series-Disseminates technical information developed at the Bureau on building materials, components, systems, and whole structures. The series presents research results, test methods, and performance criteria related to the structural and environmental functions and the durability and safety characteristics of building elements and systems.

Technical Notes-Studies or reports which are complete in themselves but restrictive in their treatment of a subject. Analogous to monographs but not so comprehensive in scope or definitive in treatment of the subject area. Often serve as a vehicle for final reports of work performed at NBS under the sponsorship of other government agencies.

Voluntary Product Standards-Developed under procedures published by the Department of Commerce in Part 10, Title 15, of the Code of Federal Regulations. The standards establish nationally recognized requirements for products, and provide all concerned interests with a basis for common understanding of the characteristics of the products. NBS administers this program as a supplement to the activities of the private sector standardizing organizations.

Consumer Information Series-Practical information, based on NBS research and experience, covering areas of interest to the consumer. Easily understandable language and illustrations provide useful background knowledge for shopping in today's technological marketplace.

Order the above NBS publications from: Superintendent of Documents, Government Printing Office, Washington, DC 20402.

Order the following NBS publications_-FIPS and NBSIR's—-from the National Technical Information Service, Springfield, VA 22161.

Federal Information Processing Standards Publications (FIPS PUB)-Publications in this series collectively constitute the Federal Information Processing Standards Register. The Register serves as the official source of information in the Federal Government regarding standards issued by NBS pursuant to the Federal Property and Administrative Services Act of 1949 as amended, Public Law 89-306 (79 Stat. 1127), and as implemented by Executive Order 11717 (38 FR 12315, dated May 11, 1973) and Part 6 of Title 15 CFR (Code of Federal Regulations).

NBS Interagency Reports (NBSIR)-A special series of interim or final reports on work performed by NBS for outside sponsors (both government and non-government). In general, initial distribution is handled by the sponsor; public distribution is by the National Technical Information Service, Springfield, VA 22161, in paper copy or microfiche form. 
(U.S. Department of Commerce

National Bureau of Standards

Gaithersburg, MD 20899

Official Business

Penalty for Private Use $\$ 300$ 